\title{
pRb controls proliferation, differentiation, and death of skeletal muscle cells and other lineages during embryogenesis
}

\author{
Eldad Zacksenhaus, ${ }^{1,2,4,5}$ Zhe Jiang, ${ }^{1,4}$ Daniel Chung, ${ }^{3}$ Jamey D. Marth ${ }^{3}$ Robert A. Phillips, ${ }^{1}$ and \\ Brenda L. Gallie ${ }^{1,5}$ \\ ${ }^{1}$ Division of Immunology and Cancer Research, Research Institute, Department of Molecular and Medical Genetics, \\ University of Toronto, The Hospital for Sick Children, Toronto, Ontario, Canada M5G 1X8; ${ }^{2}$ Breast Cancer Prevention \\ Program, Oncology Research Laboratories, Division of Hematology and Oncology, University of Toronto, The Toronto \\ Hospital, Toronto, Ontario, Canada M5G 2M1; ${ }^{3}$ Howard Hughes Medical Institute and Division of Cellular and Molecular \\ Medicine, University of California, San Diego, La Jolla, California 92093 USA
}

\begin{abstract}
Mice deficient for the $R B$ gene $\left(R^{-1-}\right)$, prior to death at embryonic day 14.5 , show increased cell death in all tissues that normally express $R B 1$ : the nervous system, liver, lens, and skeletal muscle precursor cells. We have generated transgenic mice (RBlox) that express low levels of pRb, driven by an $R B 1$ minigene. $\mathrm{RBlox} / \mathrm{RB}^{-1-}$ mutant fetuses die at birth with specific skeletal muscle defects, including increased cell death prior to myoblast fusion, shorter myotubes with fewer myofibrils, reduced muscle fibers, accumulation of elongated nuclei that actively synthesized DNA within the myotubes, and reduction in expression of the late muscle-specific genes MCK and MRF4. Thus, insufficient pRb results in failure of myogenesis in vivo, manifest in two ways. First, the massive apoptosis of myoblasts implicates a role of pRb in cell survival. Second, surviving myotubes failed to develop normally and accumulated large polyploid nuclei, implicating pRb in permanent withdrawal from the cell cycle. These results demonstrate a role for $p R b$ during terminal differentiation of skeletal muscles in vivo and place $\mathrm{pRb}$ at a nodal point that controls cell proliferation, differentiation, and death.
\end{abstract}

[Key Words: Retinoblastoma gene; differentiation; myogenesis; cell cycle control; apoptosis]

Received July 25, 1996; revised version accepted October 16, 1996.

Terminal differentiation is a dynamic process coupled to cell cycle arrest that requires continuous active control (Blau 1993). The retinoblastoma gene (RB1) product $(\mathrm{pRB})$ has been implicated in cell cycle exit and terminal differentiation. For example, SV40 large $T$ antigen, which binds and inactivates $\mathrm{pRb}$, can stimulate differentiated myotubes in culture to reenter the cell cycle /Gu et al. 1993|. RB1 is a tumor suppressor gene, absence of which predisposes individuals to retinoblastoma in infancy and, to a lesser extent, osteosarcoma in the second decade of life, at times when these tissues normally undergo terminal differentiation (for review, see Zacksenhaus et al. 1993a). Inactivation of $R B 1$ also contributes to the malignant progression of a wide spectrum of tumors including breast, prostate, lung, and bladder. Moreover, tumors with apparently normal $R B 1$ frequently contain mutations in the pathway that regulates $\mathrm{pRb}$ function,

\footnotetext{
${ }^{4}$ These authors contributed equally to this work. ${ }^{5}$ Corresponding authors.
}

resulting in inactivation of $\mathrm{pRb}$ (for review, see Weinberg 1995).

$\mathrm{pRb}$ is a member of a family of proteins including p107 (Ewen et al. 1991) and p130 (Hannon et al. 1993; Li et al. 1993) that interact with transcription factors and viral oncoproteins through shared conserved domains. The RB family of proteins exerts a negative effect on cell proliferation by modulating the activity of certain transcription factors (Defeo-Jones et al. 1991; Huang et al. 1991; Kim et al. 1992; Hagemeier et al. 1993; Wang et al. 19931, modifiers of chromatin conformation (Dunaief et al. 1994; Singh et al. 1995), proto-oncogenes (Welch and Wang 1993; Xiao et al. 1995), and differentiation factors (Gu et al. 1993; Schneider et al. 1994). The best-characterized partners for the RB family are distinct members of the E2F-DP family of transcription factors (Hijmans et al. 1995; Sardet et al. 1995; Vairo et al. 1995). Recent evidence suggests that the $\mathrm{pRb}-\mathrm{E} 2 \mathrm{~F} / \mathrm{DP}$ complex acts as a repressor unit composed of silencer $(\mathrm{pRb})$ and DNA binding (E2F/DP) subunits (Weintraub et al. 1992, 1995; Zacksenhaus et al. 1996). Mitogens and growth factors 
induce cyclin-dependent kinases (CDKs) to phosphorylate $\mathrm{pRb}$ and alleviate repression of transcription, allowing expression of E2F-responsive genes and progression through the cell cycle. Conversely, differentiation factors block CDKs and maintain $\mathrm{pRb}$ in the hypophosphorylated active form, allowing cells to exit the cell cycle and differentiate (Sherr and Roberts 1995). Surprisingly, mice lacking E2F1 develop tumors, suggesting that disruption of components of the $\mathrm{pRb}-\mathrm{E} 2 \mathrm{~F} / \mathrm{DP}$ repressor unit is tumorigenic (Field et al. 1996; Yamasaki et al. 1996).

Disruption of $R B 1$ in the mouse results in predisposition to pituitary tumors but not to retinoblastoma (Clarke et al. 1992; Jacks et al. 1992; Lee et al. 1992). Homozygous RB1-deficient mice die at embryonic day (E) 14.5 with abnormalities in erythropoiesis, neurogenesis, and lens development. The mice are anemic, the liver displays hypocellularity, and red blood cells show increased incidence of nucleated cells. In the nervous system, mitotic and apoptotic cells are observed frequently, remote from the normal proliferating zone (Lee et al. 1994). Development of the lens is also impaired with increased cell death and lack of expression of lensspecific markers (Morgenbesser et al. 1994). However, $\mathrm{RB}^{+1+}: \mathrm{RB}^{-1-}$ chimeric mice are viable and $\mathrm{RB}^{-1-}$ cells contribute to all tissues examined with variable efficiencies (Maandag et al. 1994; Williams et al. 1994), raising the possibility that the effect of $\mathrm{pRb}$ is either specific to specialized cell lineages or noncell-autonomous. Overexpression of a human $R B 1$ minigene, driven by $1.5-\mathrm{kb}$ human $R B 1$ promoter, induces dwarfism in transgenic mice (Bignon et al. 1993) and can rescue the $\mathrm{RB}^{-1-}$ defect (Lee et al. 1992).

Vertebral skeletal muscles originate from the somites and prechordal plate mesoderm (Buckingham 1992; Olson and Klein 1994). At around E14 in the mouse, myoblasts fuse to form elongated myotubes in a process governed by the MyoD family of transcription factors (Weintraub 1993). MyoD (Davis et al. 1987) and Myf5 (Braun et al. 1989) control distinct myoblast lineages (Rudnicki et al. 1993; Braun and Arnold 1996). Myoblast fusion requires myogenin (Edmondson and Olson 1989; Wright et al. 1989; Hasty et al. 1993; Nabeshima et al. 1993), whereas maintenance of the terminal differentiation state in fetal and adult muscles is apparently effected by MRF4/Myf6/herculin (Rhodes and Konieczny 1989; Braun et al. 1990; Miner and Wold 1990; for review, see Olson et al. 1996).

pRb and p107 both bind MyoD and myogenin, and these interactions are required for the onset of myogenesis in vitro (Gu et al. 1993; Schneider et al. 1994). Low serum induces differentiation of both $\mathrm{RB}^{+1+}$ and $\mathrm{RB}^{-1-}$ myoblasts in vitro; up-regulation of p107 occurs in the $\mathrm{RB}^{-1-}$ myoblasts, where it may compensate for the absence of $\mathrm{pRb}$. However, in contrast to $\mathrm{RB}^{+/+}$cells, terminal differentiation of $\mathrm{RB}^{-1-}$ myotubes is reversible and mitogens induce reentry into $S$ phase and down-regulation of pl07 (Schneider et al. 1994).

In vivo analysis of the role of $\mathrm{pRb}$ in muscle differentiation has not been possible, because $\mathrm{RB}^{-1-}$ mice die by E14.5 (Clarke et al. 1992; Jacks et al. 1992; Lee et al.
1992), prior to the stage of terminal muscle differentiation. Herein and elsewhere (Z. Jiang, E. Zacksenhaus, B.L. Gallie, and R.A. Phillips, in prep.) we show that RB1 expression is readily detected by in situ hybridization throughout skeletal myogenesis, but not in cardiac muscle, suggesting a specific requirement for $\mathrm{pRb}$ in skeletal myogenesis in vivo. We show that an $R B 1$ minigene that drives low expression of $\mathrm{pRb}$ extends the life span of $\mathrm{RB}^{-1-}$ mutant embryos to birth. The specific skeletal muscle defects in these mice reveal that each tissue that highly expresses $R B 1$ during embryogenesis /the nervous system, liver, lens, and skeletal muscle) shows evidence of impaired cell cycle regulation and defective terminal differentiation in the absence of normal levels of $p R b$.

\section{Results}

The expression pattern of $\mathrm{RB} 1$ during embryogenesis coincides with cell death in E13.5 RB $\mathrm{B}^{-1-}$ embryos

Northern blot analysis has shown that $R B 1$ is widely expressed in the adult mouse (Bernards et al. 1989). However, during embryogenesis, $R B 1$ transcripts were detected by in situ hybridization on sections in only a restricted subset of tissues (Fig. 1A,C,D). At E10.5, RB1 transcripts were seen in the myotome and other muscle precursors (Fig. 1A). The expression pattern of myogenin, an early muscle marker, overlapped in adjacent sections with $R B 1$ in muscle precursor cells at E10.5 (Fig. 1A,B). Between E13.5 and 15.5 RB1 transcripts were readily detected in the nervous system, liver, and lens, and in all differentiating striated skeletal muscles, but not in cardiac muscles (Fig. 1C). Around E14.5-15.5, myoblasts fused to form myotubes that continued to express $R B 1$ transcripts (Fig. 1D).

Abnormalities in the nervous system and the lens of E13.5 $\mathrm{RB}^{-1-}$ embryos are associated with increased cell death (Lee et al. 1994; Morgenbesser et al. 1994). To determine whether cell death is elevated in $\mathrm{RB}^{-1-}$ embryos in all tissues that normally highly express $R B 1$, we analyzed sagittal sections of E13.5 $\mathrm{RB}^{-1-}$ embryos for evidence of cell death using the TUNEL procedure, which employs terminal transferase to detect nicked DNA, the hallmark of apoptosis (Gavrieli et al. 1992). We found substantial increase in TUNEL-positive nuclei throughout the nervous system (Fig. 1E,F), particularly in dorsal root ganglia (Fig. 1G,H), and in myoblasts in the tongues of $\mathrm{RB}^{-1-}$ embryos (Fig. 1I,J). Many apoptotic nuclei were detected in the livers in normal embryos; a moderate increase was observed in $\mathrm{RB}^{-1-}$ embryos (Fig. $1 \mathrm{~K}, \mathrm{~L})$. Tissues that did not show high levels of $R B 1 \mathrm{ex}-$ pression, such as the lung and cardiac muscles, did not exhibit increased frequency of TUNEL-positive nuclei in the absence of $\mathrm{pRb}$ (Fig. 1M-P).

\section{Partial rescue of $\mathrm{RB}^{-1-}$ embryos by an $\mathrm{RB} 1$ minigene}

In order to study the effects of loss of $\mathrm{pRb}$ in tissues that develop and express $R B 1$ after the time that $\mathrm{RB}^{-1-}$ embryos die, we attempted to rescue the $\mathrm{RB}^{-1-}$ mice with 


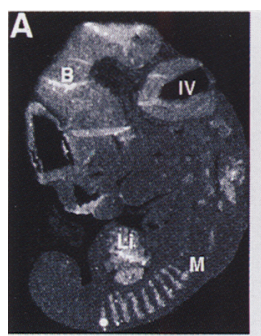

RB E10.5

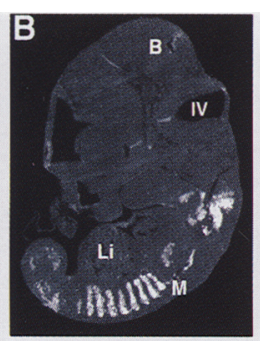

MyoG E10.5

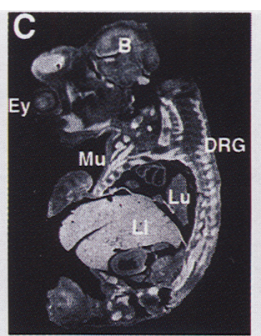

RB E13.5

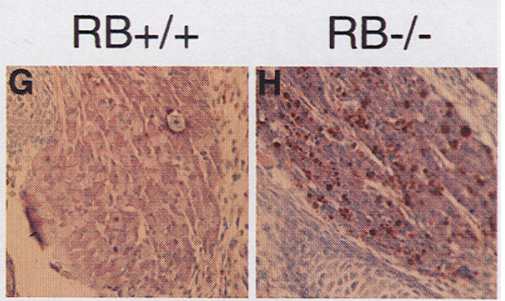

Brain

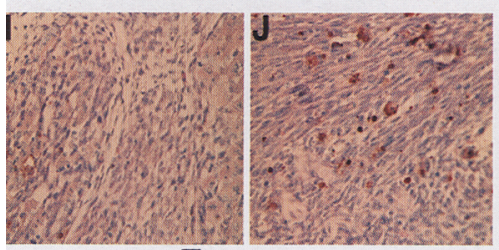

Tongue

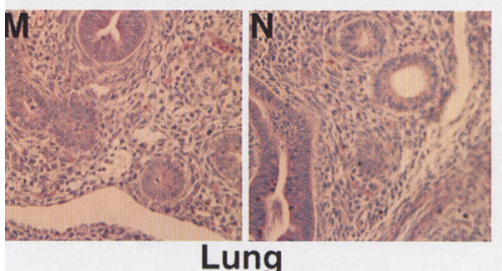

DRG

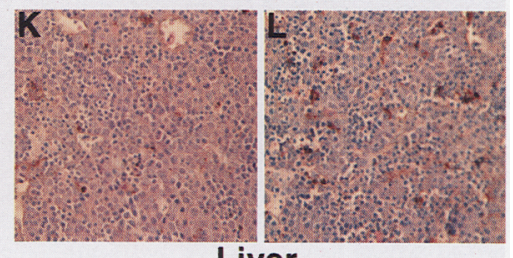

Liver

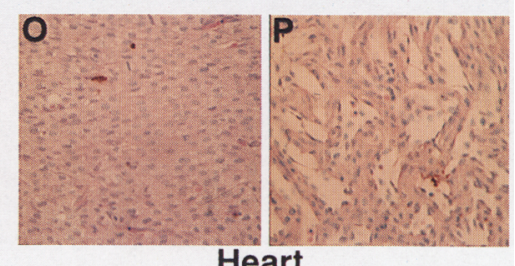

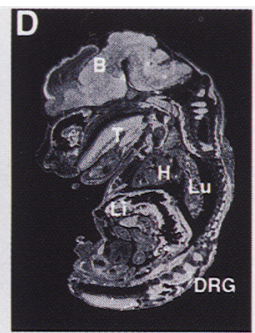

RB E15.5

RB-/Heart
Figure 1. Expression of $R B 1$ is spatially regulated and coincides with increased cell death in $\mathrm{RB}^{-1-}$ embryos. $(A, B)$ In situ localization of $R B 1(A)$ and myogenin $(B)$ in near-serial sections of E10.5 embryos. Expression of $R B 1$ and myogenin overlaps in myotomes and other muscle precursors. $(C, D)$ In situ localization of $R B 1$ in sagittal sections of $\mathrm{E} 13.5(C)$ and E15.5 (D) embryos. RB1 transcripts are detected in skeletal but not cardiac muscles. $(E-P)$ In situ apoptosis analysis of E13.5 $\mathrm{RB}^{-1-}$ embryos and $\mathrm{RB}^{+/+}$littermates; $(E, F)$ brain; $(G, H)$ $\mathrm{DRG}(I, I)$ tongue; $(K, L)$ liver; $(M, N)$ lung; $(O, P)$ heart ventricle muscle. (B) brain; (DRG) dorsal root ganglia; (Ey) eye; $(\mathrm{H})$ heart; (Li) liver; (Lu) lung; (M) myotome; $(\mathrm{Mu})$ muscles; $(\mathrm{T})$ tongue; (IV) fourth ventricle. Apoptotic nuclei are stained brown. an $R B 1$ minigene that could be deleted using the CRE/ lox system (Lakso et al. 1992; Orban et al. 1992). We constructed two RB1 minigenes. The first, RBlox1, consisted of a genomic fragment spanning the $1.3-\mathrm{kb}$ murine RB1 promoter region (Zacksenhaus et al. 1993c), the first exon and intron fused, in frame, to exons 2 to 27 of the mouse RB1 cDNA (Bernards et al. 1989), and a human growth hormone cassette that provided splicing and polyadenylation signals at the $3^{\prime}$ end (Palmiter et al. 1991) (Fig. 2A). LoxP sites were inserted into the first intron and between the RB1 stop codon and the hGH, in a tandem orientation, to allow excision of the intervening DNA sequence in the presence of CRE recombinase. Four independent founders containing the RBloxl transgene were generated and expanded into stable lines, RBlox 1-1 to 4 . Southern blot analysis indicated that the RBlox 1-3 mice had a single copy of RBlox, RBloxl-4 mice had two copies, and RBlox1-1 and 2 mice had multiple $(>5)$ copies (data not shown). Two additional founders were generated from a second minigene, RBlox2, which contained $4.8 \mathrm{~kb}$ of the mouse $R B 1$ promoter region but no intron, with loxP sites flanking the $R B 1$ cDNA /Fig. 2A).

To determine the ability of RBlox 1 to rescue the $\mathrm{RB}^{-1-}$ lethal defect at E13.5-14.5, the four lines were bred with $\mathrm{RB}^{+1-}$ mice. Weaned progeny were genotyped by PCR analysis using primers specific for the wild-type and disrupted $R B 1$ alleles (Jacks et al. 1992). No viable $\mathrm{RBlox} 1 / \mathrm{RB}^{-1-}$ offspring were detected after screening more than 200 mice from $\mathrm{RBlox} 1 / \mathrm{RB}^{+1-} \times \mathrm{RB}^{+1-}$ and $\mathrm{RBlox} 1 / \mathrm{RB}^{+/-} \times \mathrm{RBlox} 1 / \mathrm{RB}^{+/-}$crosses, using each founder. However, dead postneonatal day $0(\mathrm{PO})$ pups were detected in litters from crosses of RBlox $1-2 / \mathrm{RB}^{+/-}$ $\times \mathrm{RB}^{+1-}$ and RBlox1-4/RB ${ }^{+1-} \times \mathrm{RBlox} 1-4 / \mathrm{RB}^{+1-}$. $\mathrm{PCR}$ and Southern blot analysis of DNA extracted from these P0 pups revealed that they were $\mathrm{RBlox} 1 / \mathrm{RB}^{-/-}$ (Fig. 2B,C). At birth, the RBloxl $/ \mathrm{RB}^{-1-}$ pups had a characteristic hunchback and did not move. E17.5 and 18.5 $\mathrm{RBlox} 1 / \mathrm{RB}^{-1-}$ embryos obtained by cesarean section exhibited only a subtle response to stimulation compared with normal littermates and were analyzed in the experiments described below. The RBlox 2 transgene 
Figure 2. RBlox minigenes partially rescue the $\mathrm{RB}^{-1-}$ defect. (A) Schemata of RBlox minigenes. RBlox 1 contains a 1.3 -kb promoter region, the first exon and intron followed by exons $2-27$ of $R B 1$, and an hGH cassette. RBlox 2 contains a 4.8 -kb promoter region placed upstream of $R B 1$ cDNA followed by the hGH cassette at the $3^{\prime}$ end. Both constructs contain loxP sites, amenable to CRE mediated recombination, as indicated. Restriction enzymes: (B) BamHI; (K) KpnI; (Sa) SauI; (Sl) SalI; (Sp) SpeI; (N) NotI; (X) XbaI. (B) Genotype analysis of P0 $\mathrm{RBlox} / \mathrm{RB}^{-1-}$ mice. PCR analysis with primers that amplify the wild-type and mutant $R B 1$ alleles and the RBlox mini gene. (C) Southern blot analysis of PstI-digested DNA, hybridized with probe $a$ (Jacks et al. 1992), which discriminates the wild-type $(10-\mathrm{kb})$ and mutant $(8-\mathrm{kb})$ alleles of $R B 1 .(D)$ Immunodetection of $\mathrm{pRb}$ in E17.5 RBlox/ $\mathrm{RB}^{-1-}$ and control littermates. Protein lysates ( $1 \mathrm{mg}$ ) from the brains and carcasses of $\mathrm{RBlox} / \mathrm{RB}^{-1-}$ and control fetuses were immunoprecipitated with a monoclonal anti$\mathrm{pRb}$ antibody, fractionated on a $7.5 \%$ SDSPAGE gel, blotted, and developed with polyclonal antibody to $\mathrm{pRb}$. $(E, F)$ Immunodetection of p107 and p130 in E17.5 RBlox $/ \mathrm{RB}^{-1-}$ and control littermates. Protein lysates (150 $\mu \mathrm{g}$ ) from brains and carcasses of $\mathrm{RBlox} / \mathrm{RB}^{-1-}$ and control fetuses were immonoblotted and developed with polyclonal antibody to p107 $(E)$ or pl30(F). The bottom parts of the blots were developed with a monoclonal antibody to $\alpha$-tubulin.

also partially rescued the E13.5 $\mathrm{RB}^{-1-}$ lethal defect and $\mathrm{RBlox} 2 / \mathrm{RB}^{-1-}$ embryos showed the same phenotype as $\mathrm{RBlox} 1 / \mathrm{RB}^{-1-}$. All the experiments described below were performed with RBloxl but similar results were obtained with RBlox2.

The partial rescue of the $\mathrm{RB}^{-1-}$ defect may result from low expression or translation, possibly because of the hGH cassette at the $3^{\prime}$ end. Some other transgenes with the hGH cassette display partial splicing (Orban et al. 1992) and/or poor translation (Z. Jiang and R.A. Phillips, unpubl.). RNase protection analysis of RNA extracted from the thymus of $\mathrm{RBlox} / \mathrm{RB}^{+/-}$adult mice indicated that the transgene was expressed at $50 \%$ of endogenous $R B 1$ levels (data not shown). Western blot analysis of the brains of E17.5 RBlox $/ \mathrm{RB}^{-1-}$ embryos revealed a very low, but detectable level of $\mathrm{pRb}$; in contrast, expression of $\mathrm{pRb}$ in carcasses was undetectable (Fig. 2D). These results indicate that the RBlox transgene partially rescued the $\mathrm{RB}^{-1-}$ defects by providing still limiting levels of $\mathrm{pRb}$, enabling studies of the role of $\mathrm{pRb}$ during development between E14.5 and birth.

To determine whether the reduced level of $\mathrm{pRb}$ was accompanied by changes in the expression of p107 or p130, lysates of brains and carcasses of E17.5 RBlox/ $\mathrm{RB}^{-1-}$ embryos and control littermates were analyzed by Western blotting. To monitor equal loading, the blots were also developed with antibody to the widely expressed $\alpha$-tubulin protein. The relative levels of p107 or pl30 and $\alpha$-tubulin appeared similar in wild type and mutant embryos, suggesting that p107 and p130 were not up-regulated in response to the low levels of $\mathrm{pRb}$ in vivo (Fig. 2E,F). In addition, analysis by in situ hybridization revealed no obvious changes in the distributions of $p 107$ or $p 130$ transcripts in $\mathrm{RBlox} / \mathrm{RB}^{-1-}$ embryos (data not shown).

\section{Near normal neurogenesis in $R B l o x / R B^{-1-}$ fetuses}

We first analyzed E17.5-P0 RBlox/RB ${ }^{-/-}$fetuses for abnormalities in neurogenesis, erythropoiesis, and lens development, observed previously in E13.5 $\mathrm{RB}^{-1-}$ embryos (Clarke et al. 1992; Jacks et al. 1992; Lee et al. 1992; Morgenbesser et al. 1994). In contrast to $\mathrm{RB}^{-1-}$ embryos that fail to undergo enucleation of red blood cells, erythropoiesis proceeded almost normally in E18.5 $\mathrm{RBlox} / \mathrm{RB}^{-1-}$ fetuses, although $\sim 2-4 \%$ nucleated red blood cells were present (data not shown). A similar delay, rather than block, to erythropoiesis has been reported in $\mathrm{RB}^{+1+}: \mathrm{RB}^{-1-}$ chimeric fetuses (Maandag et al. 1994; Williams et al. 1994).

The lens fibers of $\mathrm{RBlox} / \mathrm{RB}^{-/-}$fetuses were markedly degenerated (Fig. 3A,B), similar to $\mathrm{RB}^{+1+}: \mathrm{RB}^{-1-}$ chimeric fetuses (Maandag et al. 1994; Williams et al. 1994), indicating an absolute requirement for pRb during lens development. The overall architecture of the RBlox/ $\mathrm{RB}^{-1-}$ brain and the expression of the widespread neurofilament gene, scg10, appeared near-normal (Fig. $3 C, D)$. The expression of the NGF receptors trkA and 

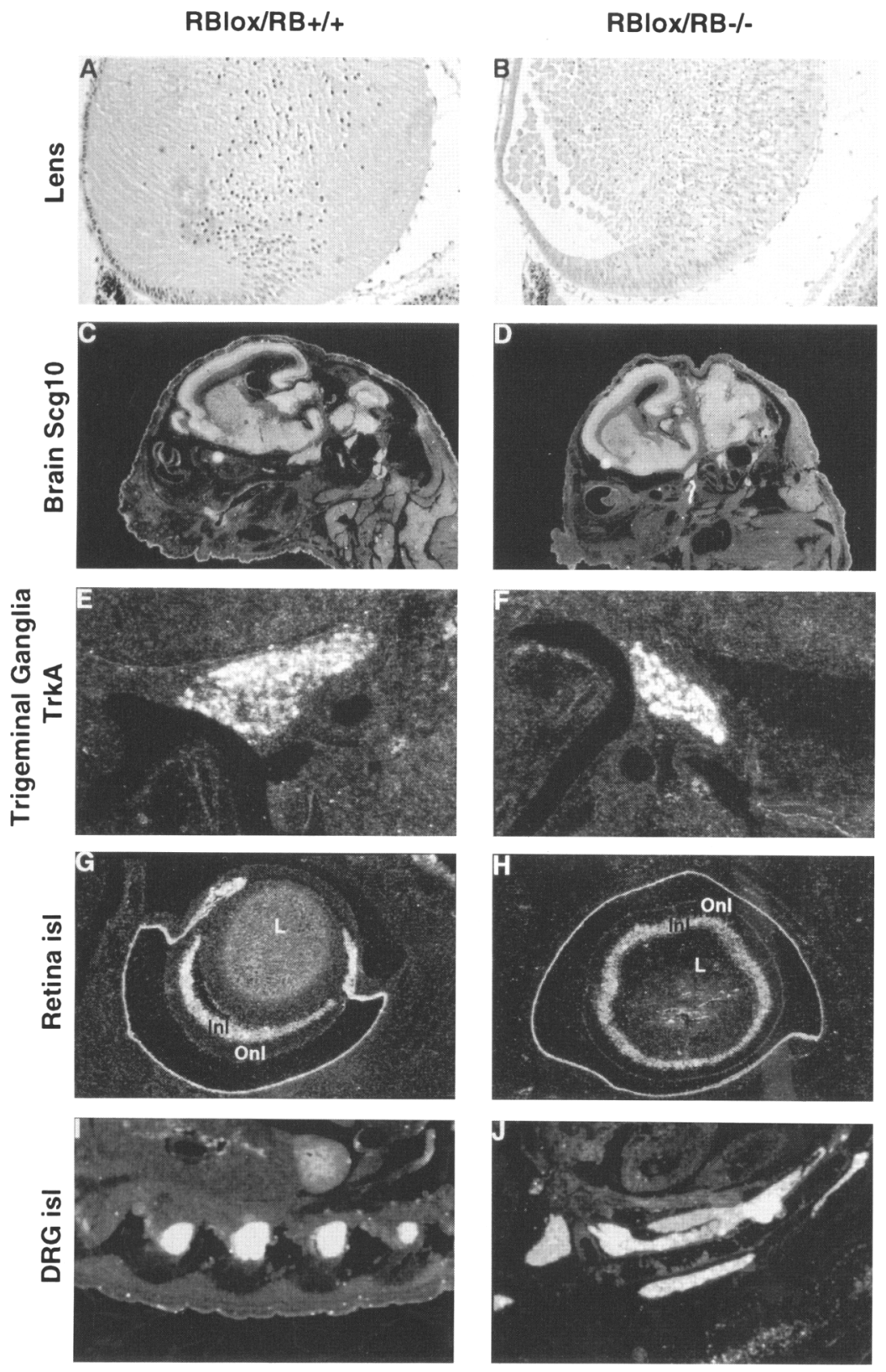

Figure 3. Neurogenesis in E17.5 RBlox/RB ${ }^{-1-}$ fetuses and control littermates. $(A, B)$ Histology of the lens of control and RBlox/RB ${ }^{-1-}$ fetuses stained with hematoxylin and eosin. $(C-I)$ In situ hybridization analyses of sagittal sections of control $(C, E, G, I)$ and RBlox/RB ${ }^{-1-}(D, F, H, I)$ fetuses with neuronal markers. $(C, D)$ Expression of $s c g 10$ in the brain. $(E, F)$ Expression of trkA in the trigeminal ganglia. $(G, H)$ Expression of islet-1 in the developing retina and lens. $(I, J)$ Expression of islet- 1 in motor neurons and DRG. (L) lens; (Inl) inner nuclear layer; (Onl) outer nuclear layer. p $75^{\text {LNGFR }}$ is down-regulated in the trigeminal ganglia of E13.5 RB $\mathrm{RB}^{-1-}$ embryos (Lee et al. 1994). In contrast, expression of trkA (Fig. 3E,F) and p $75^{\text {LNGFR }}$ (not shown) in the trigeminal ganglia of E17.5 RBlox $/ \mathrm{RB}^{-1-}$ mutant was similar to normal littermates. Likewise, expression of isl-1, a homeo box-LIM domain gene expressed in a subset of neurons, appeared unaltered in the retina, motor neurons, and dorsal root ganglia of RBlox $/ \mathrm{RB}^{-1-} \mathrm{fe}-$ tuses (Fig. 3G-J). These results suggest that near normal neurogenesis in RBlox/RB-1- fetuses is achieved by the low expression of $\mathrm{pRb}$ in the brain (Fig. 2D).

\section{Lack of cervical curvature in $R B l o x / R B^{-1-}$ mice}

The hunchback appearance of the $\mathrm{RBlox} / \mathrm{RB}^{-1-}$ mice prompted us to investigate their skeletal morphology.
Alizarin red/alcian blue staining of skeletons revealed that E18.5 RBlox/RB ${ }^{-1-}$ mice lacked normal cervical curvature (Fig. 4A,B). Otherwise, bones were present and appeared normal in shape. The abnormal posture was also evident in E17.5 and E16.5 RBlox/RB ${ }^{-1-}$ embryos (Fig. 4C-F).

E13.5 $\mathrm{RB}^{-1-}$ embryos also display a hunchback appearance, postulated previously to be attributed to enlargement of the fourth ventricle (Jacks et al. 1992). To test whether the postural defect in $\mathrm{RBlox} / \mathrm{RB}^{-/-}$embryos initiated at the perichondrium stage or after ossification, E13.5 embryos were stained with alcian blue to display cartilage. Seven of eight $\mathrm{RB}^{-1-}$ embryos displayed a hunchback and a smaller cartilaginous frame compared with wild-type embryos (Fig. 4G,I), whereas the perichondrium of $\mathrm{RBlox} / \mathrm{RB}^{-/-}$embryos was indis- 


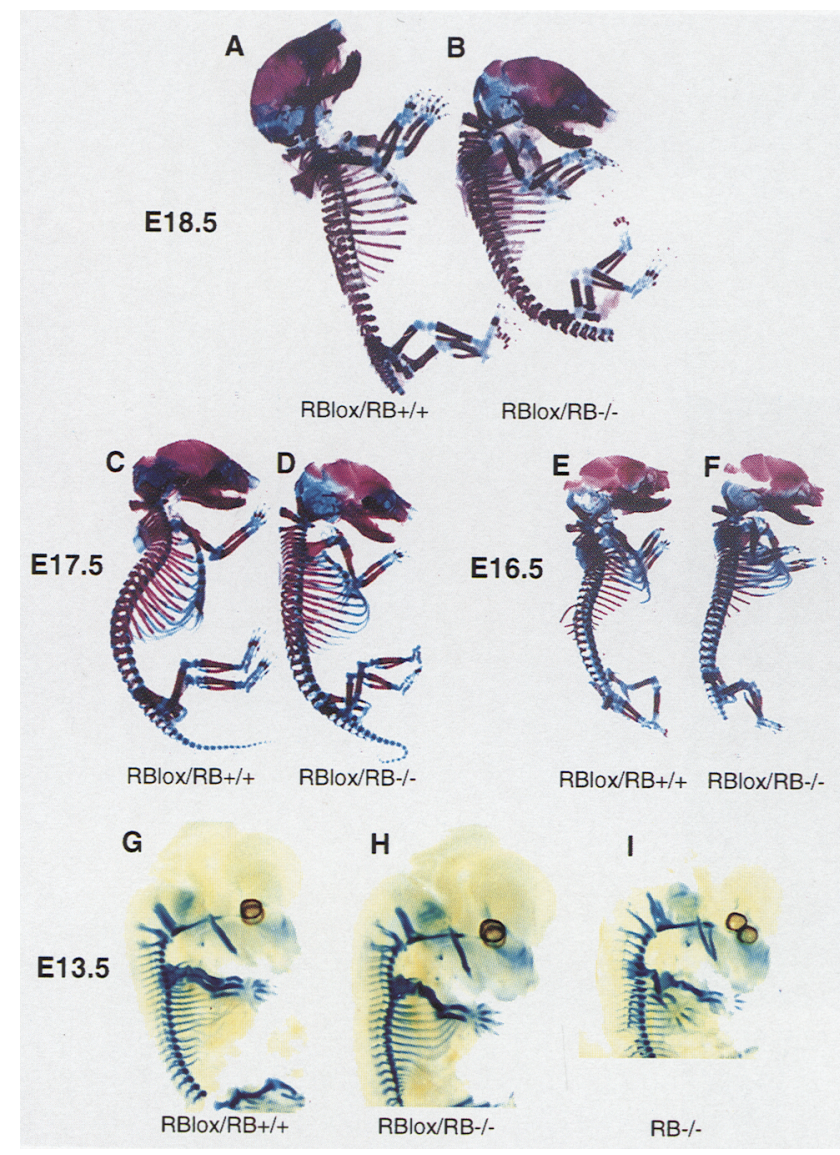

Figure 4. Lack of cervical curvature in RBlox/RB $/ \mathrm{R}^{-1-}$ fetuses $(A-F)$ Bones were stained with alizarin blue (ossification centers) and alcian red (cartilage). $(A, B) \mathrm{E} 18.5 ;(C, D) \mathrm{E} 17.5 ;(E, F)$ E16.5 fetuses. Note the lack of cervical curvature in mutant mice. $(G-I)$ Cartilage staining (alcian blue) of E13.5 embryos. $(G)$ RBlox $/ \mathrm{RB}^{+/+} ;(H), \mathrm{RBlox} / \mathrm{RB}^{-1-} ;(I) \mathrm{RB}^{-1-}$.

tinguishable from that of control $\mathrm{RB}^{+/+}$littermates (Fig. $4 \mathrm{G}, \mathrm{H})$.

\section{Abnormal morphology of RBlox/RB-1- muscles}

The lack of cervical curvature in the RBlox $/ \mathrm{RB}^{-1-}$ fetuses is very similar to the skeletal abnormality of myogenin-deficient mice that fail to develop myotubes (Hasty et al. 1993; Nabeshima et al. 1993). Histological sections through axial, tongue, and limb muscles of E16.5 to P0 RBlox/RB ${ }^{-1-}$ mice revealed reduced muscle fiber density (Fig. 5A,B and data not shown). The myotubes that were present in RBlox $/ \mathrm{RB}^{-1-}$ mice were significantly shorter than in control littermates. Most strikingly, myotubes of RBlox/RB-1- embryos contained enlarged nuclei that were two to four times longer than normal (Fig. 5B). The number of elongated nuclei increased with time, and constituted $\sim 2 \%$ and at least $10 \%$ of the myotomal nuclei in E17.5 and E18.5 RBlox/ $\mathrm{RB}^{-1-}$ embryos, respectively.

The reduced density of muscle fibers in $\mathrm{RBlox} / \mathrm{RB}^{-1-}$ embryos was evident by immunostaining with antibody to myosin heavy chain (MHC). At low magnification, MHC staining revealed reduced muscle mass in sagittal sections of RBlox/RB ${ }^{-1-}$ embryos (Fig. 5C,D). At high magnification, cross-sections through intercostal muscles showed that RBlox $/ \mathrm{RB}^{-1-}$ myotubes were widely dispersed compared with the compact arrangement of normal control muscles (Fig. 5E,F). The expression of $\mathrm{MHC}$ in the remaining myotubes of RBlox/RB ${ }^{-1-} \mathrm{em}-$ bryos was, however, relatively normal compared with control mice.

The extent of the muscle defect in RBlox/RB ${ }^{-1-}$ embryos was further analyzed by transmission electron microscopy (EM). Following the fusion of myoblasts to form myotubes, repetitive sarcomeres are assembled into long myofibrils. The myofibrils of limb and tongue muscles of E17.5 RBlox/RB ${ }^{-1-}$ embryos were shorter and less abundant than that of control littermates, though individual sarcomeric units appeared normal (Fig. 5G,H). The giant nuclei seen in stained sections (Fig. 5B) were clearly detected by EM of muscles of RBlox $/ \mathrm{RB}^{-1-}$ embryos (Fig. 5H,I). The giant nuclei were surrounded by myofibrils containing sarcoplasm, confirming that they were located within the myotubes (Fig. $5 \mathrm{H}, \mathrm{I})$.

\section{DNA synthesis and cell death in $R B l o x / R B^{-1-}$ muscles}

The proliferation status of $\mathrm{RBlox} / \mathrm{RB}^{-1-}$ muscles was examined by labeling dividing cells in utero with bromodeoxyuridine (BrdU). Pregnant females were given a single intraperitoneal injection of BrdU, and $3 \mathrm{hr}$ later embryos were recovered and tested for immunohistochemical evidence of incorporation of BrdU into DNA (Nowakowski et al. 1989; Morshead et al. 1994). In the brain of both normal and RBlox/RB ${ }^{-1-}$ fetuses, positive BrdU nuclei were found around the ventricles, whereas postmitotic areas contained fewer positive cells (Fig. 6A,B|. It was difficult to distinguish BrdU-positive nuclei within myotubes from nuclei of satellite myoblasts or other cell lineage adjacent to the myotubes (Fig. 6C). However, the giant nuclei shown by EM to be within the $\mathrm{RBlox} / \mathrm{RB}^{-1-}$ muscles stained positive for BrdU (Fig. 6D), indicating active DNA synthesis within myotubes, at a stage when DNA synthesis normally would have ceased.

Absence of $\mathrm{pRb}$ resulted in increased cell death in myoblasts of E13.5 RB ${ }^{-1-}$ embryos (Fig. 1I,J), in comparison to $\mathrm{RB}^{+1+}$ muscle. TUNEL-positive nuclei in RBlox/ $\mathrm{RB}^{+1-}$ muscles were observed only rarely (Fig. 6E). In contrast, TUNEL-positive nuclei were reproducibly detected in skeletal muscles of six different E16.5-18.5 RBlox $/ \mathrm{RB}^{-1-}$ embryos (Fig. 6F,G). Cardiac muscles of $\mathrm{RBlox} / \mathrm{RB}^{-1-}$ fetuses did not display increased cell death compared with normal mice (data not shown). This is consistent with our observation that cardiac muscles normally do not express $R B 1$ during embryogenesis (Fig. 1C,D and data not shown). 


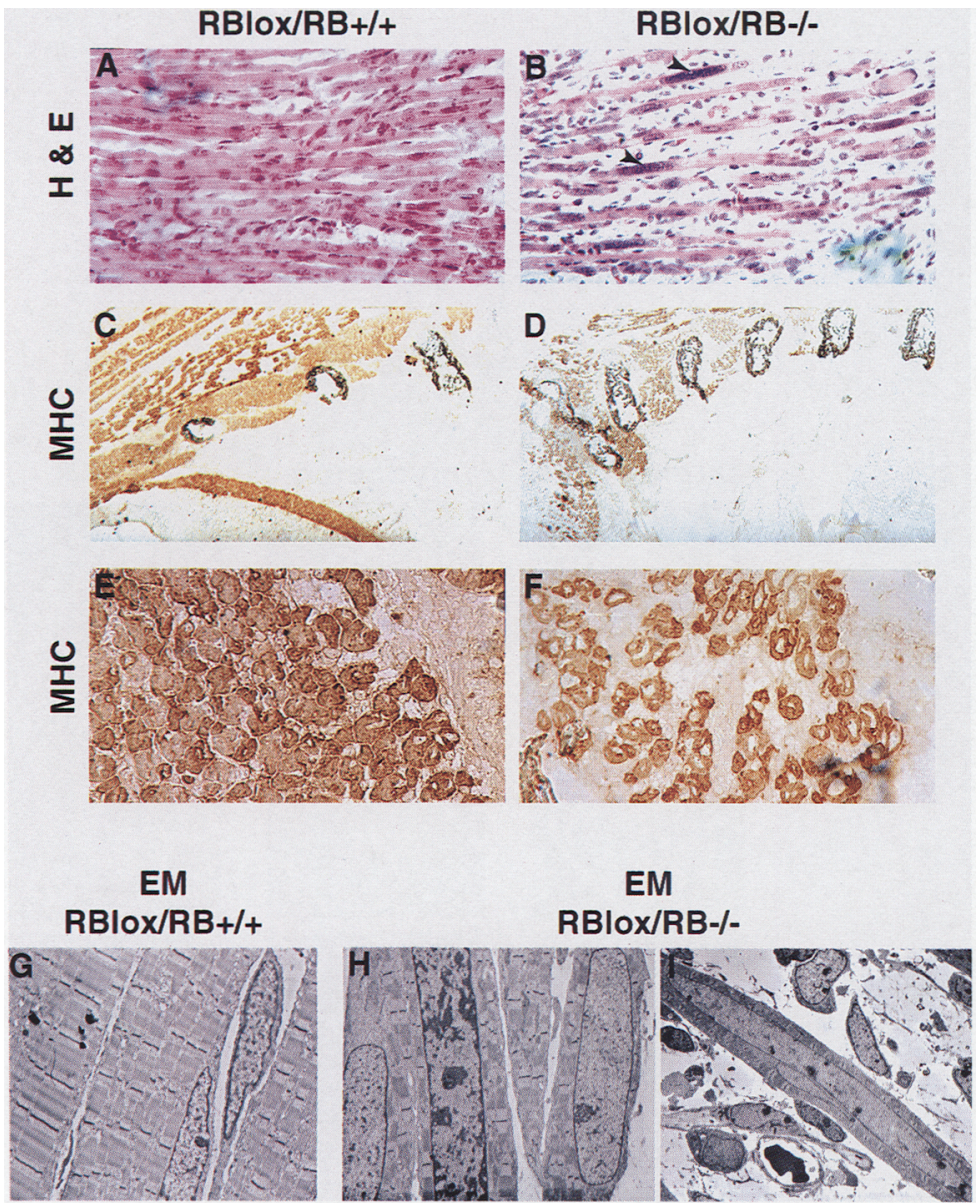

Figure 5. Abnormal myogenesis in E17.5 RBlox/ $\mathrm{RB}^{-1-}$ fetuses. $(A, B)$ Hematoxylin-eosin staining of paraffin-embedded sagittal sections through axial muscles of control $(A)$ and $\mathrm{RBlox} / \mathrm{RB}^{-1-}(B)$ fetuses. The RBlox $/ \mathrm{RB}^{-1-}$ myotubes are shorter and contain elongated nuclei (arrowheads). (C-F) Immunostaining of intercostal muscles of control $(C, E)$ and RBlox/ $\mathrm{RB}^{-1-}(D, F)$ with antibody to myosin heavy chain (MHC). Original magnifications in $C$ and $D, 200 \times ; E$ and $F, 400 \times .(G-I) \mathrm{EM}$ analysis of tongue muscles from control $(G)$ and RBlox/RB ${ }^{-1-}(H, I)$ fetuses. Original magnifications in $G$ and $H, 5600 \times ; I, 1200 \times$.

\section{Differential expression of early and late muscle markers in $R B l o x / R B^{-1-}$ fetuses}

To further analyze the consequences of inadequate $\mathrm{pRb}$ on skeletal muscle development, we examined the expression levels of several muscle-specific genes, using Northern blot hybridization with total RNA purified from carcasses of $\mathrm{RBlox} / \mathrm{RB}^{-1-}$ and control littermates. Cardiac $\alpha$-actin and myogenin are expressed early and throughout fetal myogenesis (Sassoon et al. 1988, 1989). The MCK gene is expressed from E13 onward (Lyons et al. 1991), and MHC is expressed after cell cycle exit (Pin and Merrifield 1993; Andres and Walsh 1996). MRF4/ Myf6/herculin is expressed transiently at E9-11 and then reexpressed from E15.5 to become the predominant myogenic factor in adult muscle (Bober et al. 1991; Hinterberger et al. 1991) and is regarded as a late musclespecific marker. Northern blot analysis of total RNA derived from the carcasses of $\mathrm{E} 17.5 \mathrm{RBlox} / \mathrm{RB}^{-1-}$ mice and control embryos indicated that myogenin expression was near normal, whereas expression of MCK and MRF4 was reduced greatly (Fig. 7A).

The differential expression of early and late musclespecific markers was further analyzed by in situ hybridization on sections of E17.5 embryos. The levels of cardiac $\alpha$-actin (Fig. 7B,C) and myogenin (Fig. 7D,E) ex- pressed in remaining muscle fibers of $\mathrm{RBlox} / \mathrm{RB}^{-1-}$ remained normal, although the reduced number of intact fibers resulted in an overall appearance of reduced expression. On the other hand, although all the wild-type muscle fibers expressed MRF4, only a fraction of RBlox/ $\mathrm{RB}^{-1}$ - muscles expressed this myogenic factor (Fig. $7 F, G)$. Thus, RBlox/RB-1- mutant fetuses exhibit moderate reduction of early (cardiac $\alpha$-actin, myogenin) and great reduction of late (MCK, MRF4) muscle-specific genes.

\section{Discussion}

Restricted cell lineages expressing RB1 during embryogenesis are abnormal in $R B^{-1-}$ mice

The abundant expression of RB1 in adult mice (Bernards et al. 1989) and the lack of TATA and CAAT boxes in the RB1 promoter (Hong et al. 1989; Zacksenhaus et al. 1993c) have suggested that RB1 is a "housekeeping" gene. However, the specific tissue defects of $\mathrm{RB}^{-1-}$ mice suggest a tissue specific-requirement for $\mathrm{pRb}$ during development. We demonstrate that $R B 1$ is spatially regulated during embryogenesis and that only tissues that express $R B 1$ during embryogenesis-muscles, nervous system, liver, and lens-show increased apoptosis when 


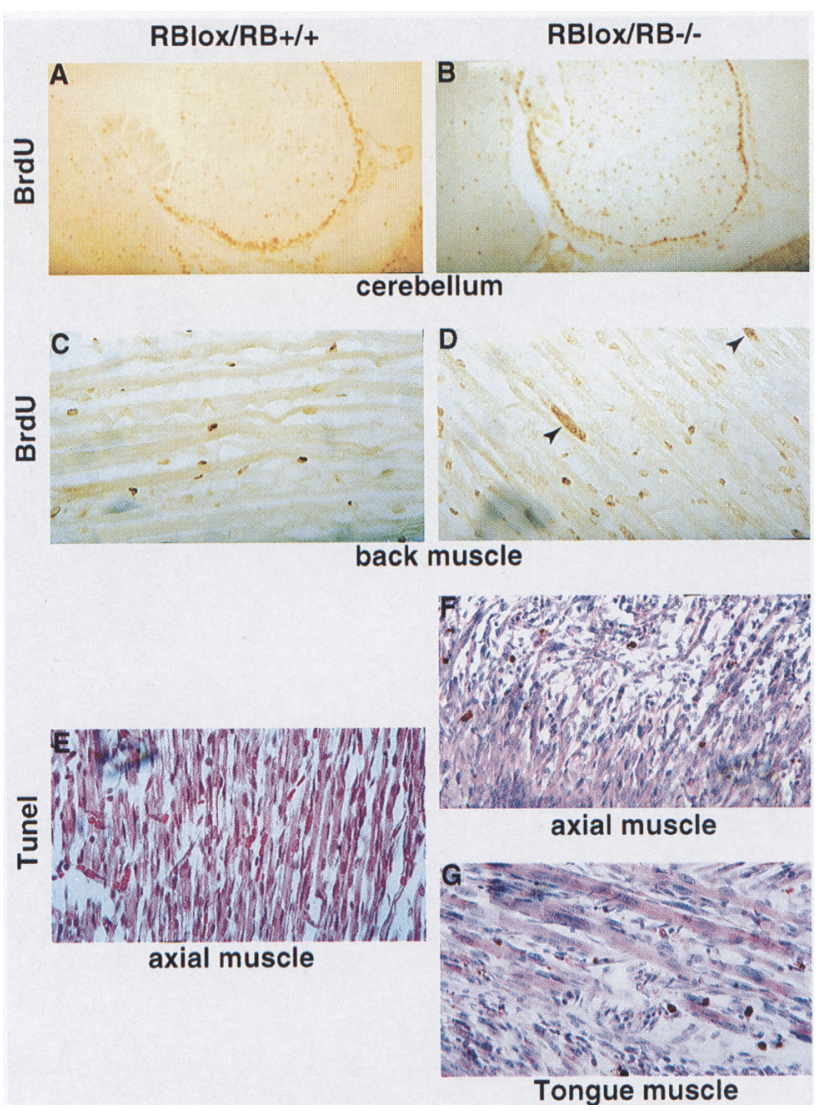

Figure 6. Abnormal DNA synthesis and cell death in E17.5 RBlox/RB ${ }^{-1-}$ muscles. $(A-D)$ Immunostaining with anti-BrdU of sagittal sections of embryos sacrificed $3 \mathrm{hr}$ after BrdU injection. $(A, B)$ Distribution of BrdU-positive nuclei in the cerebral primordium of control and $\mathrm{RBlox} / \mathrm{RB}^{-1-}$ brains, respectively. $\{C, D \mid$ BrdU-positive nuclei in back muscles of control and $\mathrm{RBlox} / \mathrm{RB}^{-1-}$ fetuses. The RBlox/RB ${ }^{-1-}$ contained BrdU-positive giant nuclei (arrows in $D \mid .(E-G)$ In situ TUNEL analysis for cell death in muscles derived from control and RBlox/ $\mathrm{RB}^{-1-}$ fetuses. $(E)$ Axial muscles of control fetus; $(F)$ axial and $(G)$ tongue muscles of RBlox/RB ${ }^{-1-}$ fetuses showing TUNELpositive nuclei.

$\mathrm{pRb}$ is absent (Fig. 1). These observations suggest that $\mathrm{pRb}$ controls the normal differentiation of restricted cell lineages.

$R B 1$ expression during embryogenesis correlated well with apoptosis in $\mathrm{RB}^{-1}-$ embryos. The levels of apoptosis varied from tissue to tissue (Fig. 1), with highest cell death observed in dorsal root ganglia. The other members of the RB family (p107 and p130) show differential expression that is distinct from $R B 1$ (Z. Jiang, E. Zacksenhaus, B.L. Gallie, and R.A. Phillips, in prep.). During embryogenesis, expression of p130 is generally very low with the highest expression in the liver; p107 is highly expressed in several tissues including the liver and central nervous system but not peripheral nervous system. Accordingly, $\mathrm{RB}^{-1-} / \mathrm{p} 107^{-/-}$mice die earlier than $\mathrm{RB}^{-1-}$ mice, with accelerated cell death in the liver and the central nervous system (Lee et al. 1996), but appar-
A
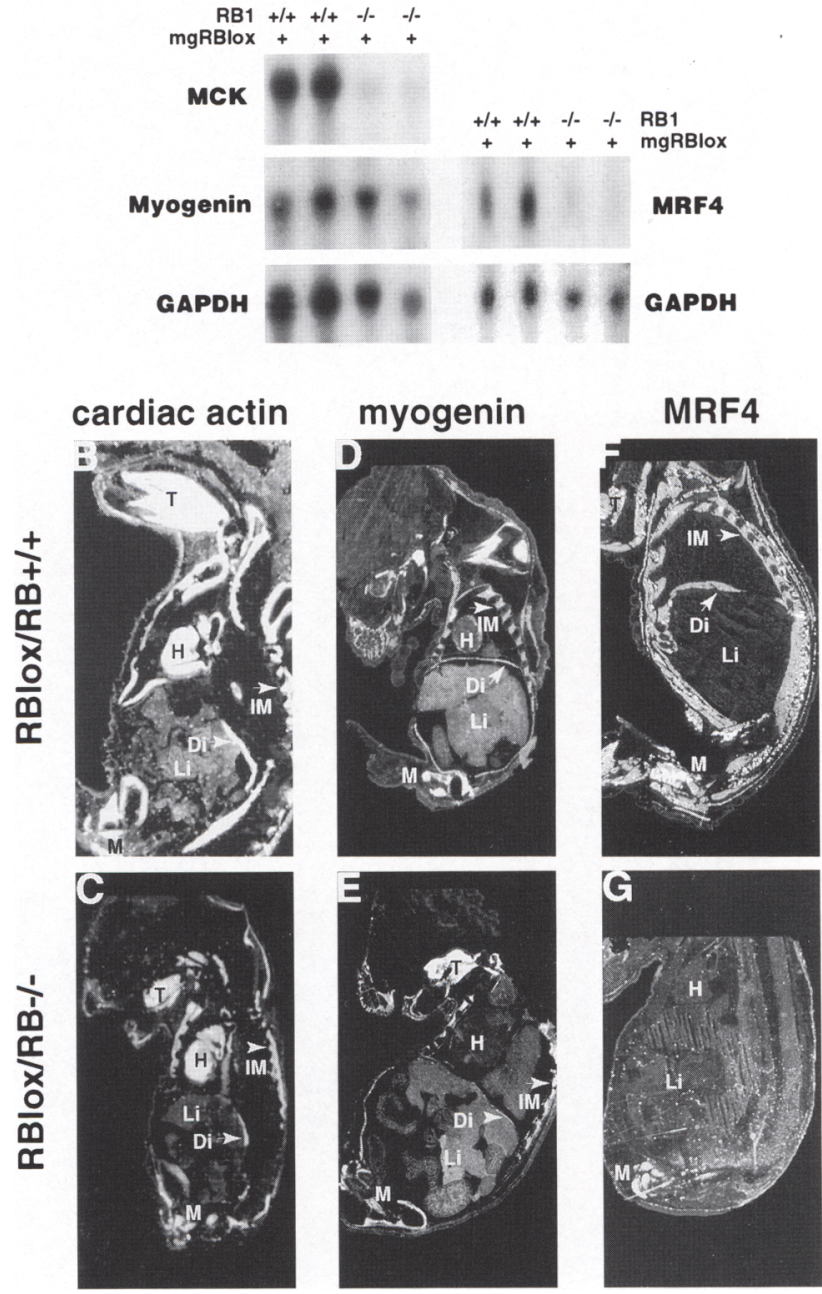

Figure 7. Abnormal expression of late muscle specific markers in E17.5 RBlox/ $\mathrm{RB}^{-1-}$ fetuses. $(A)$ Northern blot analysis of total RNA ( $40 \mu \mathrm{g}$ per lane) derived from carcasses of control and RBlox $/ \mathrm{RB}^{-1-}$ fetuses. Blots were hybridized sequentially with MCK, myogenin, and GAPDH (left panels), or with MRF4 and GAPDH (right panels). $(B-G)$ In situ hybridization analysis of mid-sagittal sections of control $(B, D, F)$ and $\mathrm{RBlox} / \mathrm{RB}^{-1-}$ $(C, E, G)$ fetuses with muscle-specific probes. $(B, C)$ cardiac $\alpha$-actin; $(D, E)$ myogenin; $(F, G)$ MRF4. (Di) Diaphragm; (H) heart; (IM) intercostal muscles; (Li) liver; (M) muscles in tail region; (T) tongue.

ently not in tissues where there is no overlap between $R B 1$ and $p 107$ expression (Z. Jiang, E. Zacksenhaus, B.L. Gallie, and R.A. Phillips, in prep.). In the $\mathrm{RB}^{-1-}$ mice, we observed the highest frequency of apoptotic nuclei in dorsal root ganglia, where $\mathrm{pRb}$ is normally strongly expressed and p107 is not expressed; the liver exhibited only twice as many apoptotic nuclei as wild type, and coexpressed all the RB family.

\section{$R B l o x / R B^{-1-}$ embryos display a muscle defect}

Partial rescue of the $\mathrm{RB}^{-/-}$mice by minigenes express- 
ing low levels of $\mathrm{pRb}$ allowed us to study the role of $\mathrm{pRb}$ in late stages of development in utero. The RBlox/ $\mathrm{RB}^{-/-}$embryos died at birth and exhibited reduced skeletal muscle mass, reduced motility, and lack of cervical curvature, reminiscent of myogenin knockout mice (Hasty et al. 1993). Although we have not determined the exact cause of death of the $\mathrm{RBlox} / \mathrm{RB}^{-1-}$ mice, loss of muscle function needed for respiration at birth is likely. While myogenin ${ }^{-1-}$ mice show very few myotubes, RBlox/RB ${ }^{-1-}$ myoblasts fused to form myotubes that were shorter, less abundant, and contained fewer myofibrils than wild type.

Expression levels of MHC, which is normally expressed in postmitotic myocytes (Pin and Merrifield 1993; Andres and Walsh 1996), $\alpha$-cardiac actin, and myogenin were reduced in proportion to the reduced muscle mass in $\mathrm{RBlox} / \mathrm{RB}^{-1-}$ mice, but the remaining cells appeared to express these genes at normal levels. However, the myofibrils were disorganized and less abundant than wild type (Fig. 5). In contrast, expression of MCK and MRF4 was almost absent, although rare myotubes still showed expression of MRF4 (Fig. 7). Thus, the RBlox/ $\mathrm{RB}^{-1-}$ defect had the greatest effect on late markers (MRF4 and MCK), whereas expression of earlier markers $(\alpha$-cardiac actin, myogenin, and MHC) was less affected (Figs. 5,7,8). We did not test MyoD or Myf5 expression; however, the later markers, myogenin and $\mathrm{MHC}$, were near-normal in $\mathrm{RBlox} / \mathrm{RB}^{-/-}$embryos.

TUNEL analysis of E13.5 $\mathrm{RB}^{-1-}$ embryos revealed substantial cell death in muscle masses before the onset of terminal differentiation (Fig. 1). Muscles of RBlox/ $\mathrm{RB}^{-1-}$ mice also displayed increased cell death compared with control littermates (Fig. 6). Many TUNELpositive nuclei appeared outside myotubes, suggesting that apoptosis was the outcome of insufficient $\mathrm{pRb}$ prior to myoblast fusion.

Within the RBlox/RB ${ }^{-1-}$ myotubes nuclei two to four times longer than normal were observed that were actively synthesizing DNA, in contrast to normal myotubes where no DNA synthesis occurs. Ectopic DNA synthesis has also been observed in the marginal zone of the neural tube in $\mathrm{RB}^{-1-}$ embryos (Lee et al. 1994).
However, whereas apoptosis followed the abnormal reentry of neurons into S phase (Lee et al. 1994), aberrant DNA duplication in myotubes resulted in accumulation of giant nuclei that did not show apoptosis (Fig. 5). We note that SV40 large T antigen, which binds and inactivates $\mathrm{pRb}$ as well as other cellular proteins, induces tetraploidy in certain cell types (Ornitz et al. 1987; Kuhar and Lehman 1991; Rinehart et al. 1992, 1993). In addition, exocrine tissues of E2F1 ${ }^{-/-}$mice contain cells with abnormally large nuclei and binucleated cells (Field et al. 1996; Yamasaki et al. 1996). Thus, disruption of the pRb-E2F repressor unit may lead to abnormal entry into $S$ phase in certain differentiated cells. The specific outcome of disruption of the $\mathrm{pRb}$ pathway depends on the cell type, ranging from inappropriate proliferation thuman developing retinal, to inappropriate entry into $S$ phase leading to either apoptosis (certain neurons and hematopoietic cells, lens, early muscle precursors) or to endoreduplication without mitosis (myotubes).

\section{Role of $p R b$ in myogenesis}

Accumulated evidence supports a cell-autonomous role for $\mathrm{pRb}$ in terminal differentiation of muscles: (1) MyoD and myogenin bind pRb /Gu et al. 1993; Schneider et al. 1994), and the presence of $\mathrm{pRb}$ is necessary for the induction of differentiation by these myogenic factors in vitro (Schneider et al. 1994). (2) We show that during embryogenesis, $R B 1$ is specifically expressed at high levels during skeletal myogenesis (Fig. 1). (3) Massive myoblast cell death occurs in $\mathrm{RB}^{-1-}$ embryos at E13.5, prior to differentiation into myotubes (Fig. 1). (4) The RBlox/ $\mathrm{RB}^{-1-}$ phenotype appears to recapitulate the behavior of $\mathrm{RB}^{-1-}$ myoblasts in vitro, which are unable to differentiate terminally and instead remain sensitive to mitogenic stimulation and reenter $S$ phase (Schneider et al. 1994). The RBlox/RB ${ }^{-/-}$myoblasts form myotubes, but continue to progress into $\mathrm{S}$ phase without the capacity to pass through mitosis, resulting in greatly elongated nuclei. (5) Although we cannot rule out the possibility that $\mathrm{RBlox} / \mathrm{RB}^{-1-}$ mice suffer from some subtle neurological abnormalities, we observed near-normal neurogenesis in

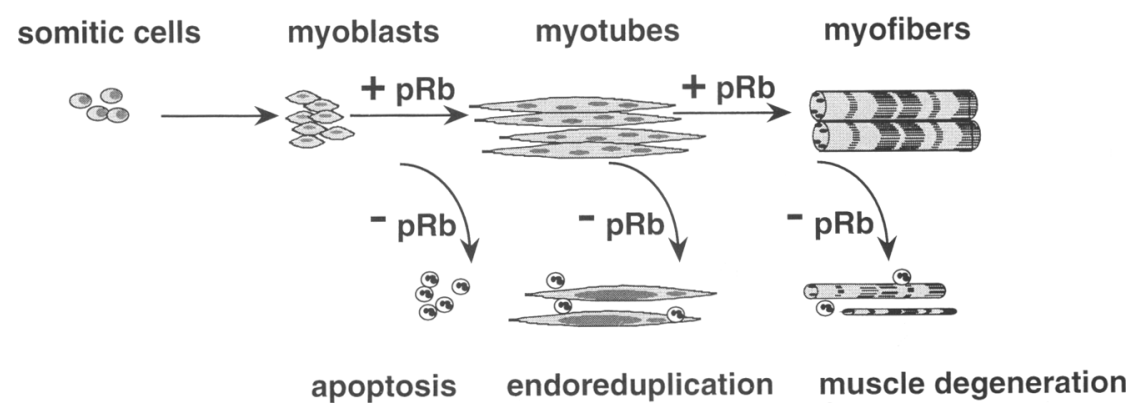

apoptosis endoreduplication muscle degeneration
Figure 8. Model for the role of $\mathrm{pRb}$ in myogenesis. Myoblast differentiation is controlled by the sequential activities of MyoD and Myf5 required for distinct muscle lineages, myogenin for myoblasts fusion, and MRF4 for maturation of the muscle fiber (adapted from Zhang et al. 1995). In the absence of $\mathrm{pRb}$, terminal withdrawal from the cell cycle is hampered, resulting in an increase in apoptosis prior to cell cycle exit, abnormal DNA endoreduplication in the myotube, and muscle regeneratio some RB-deficient nuclei manage to differentiate in the absence of $\mathrm{pRb}$. 
$\mathrm{RBlox} / \mathrm{RB}^{-1-}$ mice as judged by histological analysis and the expression patterns of several neuronal markers (Fig. 3). The low expression of the RBlox transgene in the brain of RBlox/RB $/ \mathrm{B}^{-1-}$ fetuses (Fig. 2D) appears sufficient to support neurogenesis, and the lethal phenotype appears to be the muscle defect. (6) Fusion of $\mathrm{RB}^{+/+}$and $\mathrm{RB}^{-1-}$ myoblasts may rescue $\mathrm{RB}^{-1-}$ nuclei within myotubes in chimeric $\mathrm{RB}^{+/+}: \mathrm{RB}^{-1-}$ mice (Maandag et al. 1994; Williams et al. 1994). (7) Expression of the cdk inhibitor $\mathrm{p} 21$, which activates $\mathrm{pRb}$ by blocking cyclin/ cdk phosphorylation, blocks apoptosis normally induced in the myoblast cell line, $\mathrm{C}_{2} \mathrm{C}_{12}$, upon differentiation in vitro (Wang and Walsh 1996). (8) Fiddler et al. (1996) found that amplification of MDM2 also blocks terminal myogenesis. Although a major target of MDM2 is p53, Xiao et al. (1995) observed that MDM2 also binds and inactivates $\mathrm{pRb}$.

The expression of p107 or p130 is not markedly elevated in E17.5 RBlox/RB ${ }^{-1-}$ mice (Fig. $2 \mathrm{E}, \mathrm{F}$ ). During myogenesis, expression of p107 and $p 130$ is not detectable by in situ hybridization (Z. Jiang, E. Zacksenhaus, B.L. Gallie, and R.A. Phillips, in prep.), although both proteins are readily detected by immunoblots of protein lysates prepared from whole carcasses (Fig. 2). In situ hybridization analysis of E13.5 RB-1- embryos (Z. Jiang E. Zacksenhaus, B.L. Gallie, and R.A. Phillips, in prep.) and E15.5 and E17.5 RBlox/RB ${ }^{-1-}$ embryos for $p 107$ and p130 expression revealed no detectable increase in muscle or any other tissue, compared with normal littermates (data not shown). It is possible that where normally expressed, p107 and p130 partially compensate for the lack of $\mathrm{pRb}$. Mice deficient in both $\mathrm{pRb}$ and $\mathrm{p} 107$ die earlier than $\mathrm{RB}^{-1-}$ mice, at E11.5, when they show no apparent myogenic defects (Lee et al. 1996). However, muscle development is only rudimentary at this stage. $\mathrm{RBlox} / \mathrm{RB}^{-1-} / \mathrm{pl} 107^{-1-}$ mice would test whether $\mathrm{p} 107$ compensates for the lack of $\mathrm{pRb}$ during terminal myogenesis.

How pRb affects myogenesis at the molecular level is yet to be determined. The $\mathrm{pRb}-\mathrm{MyoD}$ complex could activate muscle-specific genes by a mechanism similar to the MyoD-MEF2 interaction (Molkentin et al. 1995). However, supershift analyses with antibodies to MyoD or $\mathrm{pRb}$ failed to detect complexes on E2F or MyoD (E box) binding sites (Gu et al. 1993; Halevy et al. 1995). A model that does not assume direct interaction between $\mathrm{pRb}$ and MyoD has also been suggested (Halevy et al. 1995; Skapek et al. 1995). In this model, MyoD up-regulates the expression of the cdk inhibitor p21, thereby blocking proliferation by inhibiting the phosphorylation and inactivation of $\mathrm{pRb}$. However, the normal expression of $\mathrm{p} 21$ in muscles of $\mathrm{MyoD}^{-1-} /$ myogenin $^{-1-}$ embryos (Parker et al. 1995), and the normal development and myogenesis of mice lacking p21 (Deng et al. 1995) suggest that $\mathrm{p} 21$ plays a minor or redundant role.

\section{Model for $p R B$ in myogenesis and embryogenesis}

Starting in somatic cells, the sequential expression of muscle-specific genes leads to a series of differentiation events culminating in the organization into functional muscle fibers (Fig. 8). Our data indicate that $\mathrm{pRb}$ is required at the time when myoblasts make a final exit from the cell cycle and differentiate terminally. We propose that the lack of $\mathrm{pRb}$ increases the probability of apoptosis as a consequence of inability of $\mathrm{RB}^{-1-}$ cells to withdraw permanently from the cell cycle. In our model, differentiating $\mathrm{RB}^{-1-}$ cells appear to have variable fates, probably depending on the fluctuating levels of mitogenes and differentiating factors in the cells. $\mathrm{pRb}$ is required for both maintenance of myoblasts (otherwise apoptosis occurs in $\mathrm{RB}^{-1-}$ mice) and differentiation of myotubes to mature myofibers (otherwise apoptosis and endoreduplication of DNA occurs in RBlox/RB-1- mice) (Fig. 8).

This model suggests that $\mathrm{pRb}$ is necessary for terminal withdrawal from the cell cycle but that some $\mathrm{RB}^{-1-}$ cells may differentiate even in the absence of $\mathrm{pRb}$. This is consistent with the phenotype of $\mathrm{RB}^{-1-}$ and RBlox/ $\mathrm{RB}^{-1-}$ mutant mice and with the observation that fresh retinoblastoma tumors and retinoblastoma cell lines retain some potential to differentiate in vitro (Seigel and Notter 1993; Seigel et al. 1994). The model also accounts for the variable capacity of $\mathrm{RB}^{-1-}$ cells to contribute to adult tissues in $\mathrm{RB}^{+/+}: \mathrm{RB}^{-1-}$ chimeric mice. The reduced contribution of $\mathrm{RB}^{-1-}$ cells to the central nervous system (CNS) is consistent with the increased apoptosis in this pRb-dependent tissue (Fig. 1). Some nucleated red blood cells are present in both $\mathrm{RB}^{+1+}$ : $\mathrm{RB}^{-1-}$ and $\mathrm{RBlox} / \mathrm{RB}^{-1-}$ fetuses, suggesting that erythropoiesis is delayed rather than blocked in the absence of $\mathrm{pRb}$. As noted earlier, $\mathrm{RB}^{-1-}$ myoblasts may contribute to myogenesis in $\mathrm{RB}^{+1+}: \mathrm{RB}^{-1-}$ chimeric mice by fusing to $\mathrm{RB}^{+1+}$ myoblasts. Finally, $\mathrm{pRb}$ appears to be absolutely required for lens development; cell death and disorganization of the lens fibers occur in $\mathrm{RB}^{-1-}$, $\mathrm{RB}^{+1+}: \mathrm{RB}^{-1-}$ chimera, and RBlox $/ \mathrm{RB}^{-1-}$ mice. In human retinoblasts, the probability of apoptosis in the absence of $\mathrm{pRb}$ may be lower than in other tissues, leaving the opportunity for clonal expansion and ultimately retinoblastoma.

\section{Methods \\ Plasmids and probes}

mgRblox-1 and mgRBlox-2 were constructed using the $R B 1$ mouse promoter region (Zacksenhaus et al. 1993c), cDNA (Bernards et al. 1989), and a human growth hormone ( $\mathrm{hGH}$ ) cassette, using standard cloning procedures. Two complementary 56-mer oligos (5'-GATCCGGAACCCTTAATATAACTTCGTATAATGTATGCTATACGAAGTTATTAGGTCC- $3^{\prime}$ ) were used to generate the loxP site and flanking DNA sequences from bacteriophage Pl. Expression of mgRblox-1 and mgRBlox-2 was confirmed by immunostaining and Western blots in transiently transfected C33A cells.

Myogenin and MRF4 expression plasmids were kindly furnished by Cathy Prody (Hospital for Sick Children, Toronto, Ontario, Canada). To make specific riboprobes, the myogenin cDNA was subcloned as an EcoRI fragment into pGEM-7; 
a 700-bp KpnI-XbaI fragment of MRF4 cDNA was subcloned into pBluescript-KS. The rat NGF receptor plasmids, $\mathrm{p} 75^{L N G F R}$ and trkA, were received from Phil A. Baker (Montreal Neurological Institute and Hospital, Quebec, Canada). The scg10 probe was obtained from B. Motro (University of Bar Illan, Israel), the MCK probe from P. Hamel (University of Toronto, Ontario, Canada), the Islet-1 probe from C.C. Hui (Hospital for Sick Children), and cardiac- $\alpha$-actin from J. Rossant (Mount Sinai Hospital, Toronto, Ontario, Canada).

\section{Animals and transgenic mice}

The $\mathrm{RB}^{+/-}$mice were kindly provided by $\mathrm{T}$. Jacks (Massachusetts Institute of Technology, Cambridge), and genotyped by PCR as described (Jacks et al. 1992). $\mathrm{RB}^{-1-}$ embryos were derived from breeding $\mathrm{RB}^{+1-}$ heterozygotes. $\mathrm{mgRblox}-1$ and $\mathrm{mgR}$ Blox- 2 insert DNAs were released from the vector by digestion with the restriction enzyme SpeI, purified and injected into pronuclei as described (Orban et al. 1992). Copy number was assessed by Southern blot analysis with PstI, EcoRI, and Sall, which cut mgRblox-1 once, followed by hybridization with a fragment, NotI-BamHI, from the first intron of RB1. The RBloxl and mgRBlox 2 transgenes were detected by PCR using an oligo $\left(5^{\prime}\right.$-ATTTCAGAAGGTCTGCCAAC-3') for exon 23 of $R B 1$ and a second oligo $\left(5^{\prime}\right.$-AGAGCAGGCCAAAAGCCAGGA$3^{\prime}$ ) for exon 2 of hGH. The wild-type and mutant alleles of the $R B l$ knockout gene were detected by PCR and Southern blot as described (Jacks et al. 1992). PCR conditions for the alleles (RBlox, $\mathrm{RB}+, \mathrm{RB}-$ ) were $94^{\circ} \mathrm{C}$ (denaturation), $58^{\circ} \mathrm{C}$ (annealing), and $72^{\circ} \mathrm{C}$ (extension), 1 min each for 30 cycles. For embryonic staging, the morning of vaginal plug observation was considered as E0.5. Pregnant females were sacrificed by cervical dislocation and embryos were retrieved. For histology, embryos were transferred to freshly made $4 \%$ paraformaldehyde in PBS and fixed overnight at $4^{\circ} \mathrm{C}$. The embryos were washed several times in $70 \%$ ethanol in PBS, paraffin embedded, and sectioned at $8 \mu \mathrm{m}$.

\section{Skeletal analysis}

E13.5 embryos were stained for cartilage with Alcian blue as described (Jegalian and De Robertis 1992). Alcian blue and alizarin red staining for cartilage and bones of E16-18 fetuses was performed as in Lufkin et al. (1992), except that after overnight fixation in $95 \%$ ethanol, the skin, muscles, and viscera were removed.

\section{Immunohistochemical staining}

Embryos from timed pregnancy females were immersed in OCT (Miles) and frozen in liquid nitrogen. Cryosections $(8 \mu \mathrm{m})$ were fixed and permeabilized for $20 \mathrm{~min}$ in $100 \%$ acetone at room temperature, washed in PBS, and immunostained with $\mathrm{MHC}$ monoclonal antibody (1:100, SIGMA) as described (Zacksenhaus et al. 1996).

\section{Western blots, immunoprecipitation, and RNase protection}

Single-cell suspensions in PBS were prepared from brains, carcasses, and livers of E13.5 embryos by sonication. After brief spin, the tissue pellets were resuspended and lysed in EBC 150 $\mathrm{mm}$ Tris at $\mathrm{pH} 7.4 ; 0.5 \% \mathrm{NP}-40 ; 150 \mathrm{mM} \mathrm{NaCl}$ plus the proteinase inhibitors PMF, aprotenin, and leupeptin). pRb was immunoprecipitated with monoclonal antibody G3-245 (PharMingen) followed by antimouse IgG conjugated to agarose (Sigma) and washed six times each in EBC plus $1 \%$ deoxycholate (DOC) and $0.1 \%$ SDS, as described (Zacksenhaus et al. 1993b). Proteins were fractionated on $7.5 \%$ SDS-PAGE gels, transferred to nitrocellulose membranes, and immunoreacted with rabbit polyclonal antibodies to $\mathrm{pRb}$ (C-15, Santa Cruz Biotechnology), p130 (C-20, Santa Cruz Biotechnology), or p107 (C-18, Santa Cruz Biotechnology) at a dilution of $0.3 \mu \mathrm{g} / \mathrm{ml}$, or with monoclonal anti- $\alpha$-tubulin (Sigma) at $0.125 \mu \mathrm{g} / \mathrm{ml}$. Antirabbit and antimouse secondary antibodies conjugated to horseradish peroxidase were used at 1:8000 and 1:4000 dilution, respectively. The blots were developed with an ECL kit from Amersham.

RNase protection was performed as described (Zacksenhaus et al. 1993cl, except that total RNA was isolated from thymus of RBlox $/ \mathrm{RB}^{+1-}$ mice with Trizol (GIBCO-BRL). The riboprobe allowed detection of both endogenous and transgenic $R B 1$.

\section{Electron microscopy}

Legs and tongues of E17.5 and E18.5 embryos were removed and quickly stretched and fixed in EM-grade $2 \%$ glutaraldehyde and $4 \%$ paraformaldehyde in $0.1 \mathrm{M}$ phosphate buffer $(\mathrm{pH} 7.2)$ and processed for EM. Sections were viewed and photographed with an Hitachi H-600 electron microscope.

\section{In situ hybridization}

In situ hybridization was performed exactly as described (Hui et al. 1994). Riboprobes were labeled with ${ }^{35}$ S-UTP, purified on a G50 column (Pharmacia) and used at $2 \times 10^{5} \mathrm{cpm} / \mu$ lexcept for Isl-1 and cardiac actin $\left(0.5 \times 10^{5} \mathrm{cpm} / \mu \mathrm{l}\right)$. Hybridizations were carried out overnight at $55^{\circ} \mathrm{C}$. High stringency conditions, including two washes at $65^{\circ} \mathrm{C}$ in $50 \%$ formamide and RNase digestion, removed nonspecific binding of the probes. The slides were finally dipped into NTB-2 emulsion (kodak), exposed at $4^{\circ} \mathrm{C}$ for three weeks, developed, and stained with toluidine blue.

\section{In situ analysis of cell death (TUNEL)}

TUNEL (TdT-mediated UTP-biotin nick end labeling) (Gavrieli et al. 1992/ was performed as following. Tissues were fixed in $4 \%$ paraformaldehyde prior to embedding in paraffin, and $8 \mu \mathrm{m}$ sections were spread on 3-amino-propyl-triethoxy-silane (Sigma)-coated slides and dried at $42^{\circ} \mathrm{C}$ overnight. Measures were taken to minimize the presence of DNases. Sections were deparaffinated and hydrated by immersing in xylene twice for 5 min, for 3 min each in $96 \%, 90 \%$, and $80 \%$ ethanol, and, finally, in double distilled water (ddw). Slides were immersed in PBS for $5 \mathrm{~min}$, incubated with $5 \mu \mathrm{g} / \mathrm{ml}$ proteinase $\mathrm{K}$ in PBS for $2 \mathrm{~min}$ at $\mathrm{RT}$ and then washed twice in PBS and twice in ddw for $5 \mathrm{~min}$ each. Endogenous peroxidases were destroyed by treating with $3 \% \mathrm{H}_{2} \mathrm{O}_{2}$ for $15 \mathrm{~min}$. The slides were rinsed with ddw three times for $3 \mathrm{~min}$ and then equilibrated under plastic cover slips in $1 \times \mathrm{TdT}$ buffer, made by dilution from $10 \times \mathrm{TdT}(0.3 \mathrm{M}$ Tris, $1.4 \mathrm{M}$ Na-cacodylate at pH $7.210 \mathrm{~mm}$ cobalt chloride, $3 \% \mathrm{BSA}$ ) for $30 \mathrm{~min}$ at $37^{\circ} \mathrm{C}$. Prewarmed reaction mixture (in $1 \times \mathrm{TdT}$ buffer $10 \mu \mathrm{M}$ bio-16-dUTP ( $1 \mathrm{mM}$ stock), 0.2 units TdT, and $3 \%$ BSA) was added and slides were incubated in a humid atmosphere for $60 \mathrm{~min}$ at $37^{\circ} \mathrm{C}$. The reaction was terminated by washes with prewarmed $4 \times$ SSC, twice for $15 \mathrm{~min}$ at $37^{\circ} \mathrm{C}$ with intermittent shaking. Slides were washed twice for $2 \mathrm{~min}$ in PBS and twice for $2 \mathrm{~min}$ in $1 \times$ PBS-0.1\% Triton X-100 (PBS-T). ABC reagent (Vectastain) was added for $1 \mathrm{hr}$. The slides were washed twice for $5 \mathrm{~min}$ in PBS-T followed by two washes in $50 \mathrm{~mm}$ Tris at $\mathrm{pH} 7.4$. The slides were immersed in $\mathrm{DAB}(1.5 \mathrm{mg} / \mathrm{ml}$ in 50 $\mathrm{mM}$ Tris at $\mathrm{pH} 7.4)$ and $0.05 \% \mathrm{H}_{2} \mathrm{O}_{2}$ for $7 \mathrm{~min}$. The slides were washed with ddw, counterstained with methyl green $(0.5 \% \mathrm{wt} /$ vol in $0.1 \mathrm{M}$ sodium acetate at $\mathrm{pH} 4.0$, adjusted with acetic acid) for $10 \mathrm{~min}$, and then washed again in $\mathrm{ddw}$ followed by $100 \%$ butanol three times for $30 \mathrm{sec}$, prior to mounting. 


\section{BrdU injection and immunodetection}

Pregnant mice were given a single intraperitoneal (IP) injection of $\mathrm{BrdU}$ (Sigma) at $100 \mathrm{mg} / \mathrm{kg}$ body weight. Three hours later, the mice were sacrificed and their embryos were fixed in Bouin's solution overnight and processed as for in situ hybridization. BrdU immunostaining (Morshead et al. 1994; Nowakowski et al. 1989) was performed as follows. Paraffin sections ( $8 \mu \mathrm{m}$ ) were treated with xylene ( 3 changes of $10 \mathrm{~min}$ each) and rehydrated through graded alcohols: $100 \%$ twice for $5 \mathrm{~min} ; 95 \%$ twice for $5 \mathrm{~min}$; and $3 \mathrm{~min}$ each of $80 \%, 70 \%, 50 \%$, and ddw. The slides were treated with $0.1 \%$ trypsin in $0.1 \mathrm{M}$ Tris buffer $(\mathrm{pH} 7.4)$ with $0.1 \% \mathrm{CaCl}_{2}$ at $37^{\circ} \mathrm{C}$ for $20 \mathrm{~min}$ and then washed in PBS twice for $1 \mathrm{~min}$. Denaturation in $3 \mathrm{~N} \mathrm{HCl}$ for $50 \mathrm{~min}$ was followed by neutralization in PBS plus $1 \%$ BSA. Blocking solution $11 \%$ BSA and $0.5 \%$ Tween 20 in PBS/ was applied, followed by anti-BrdU (Becton Dickenson, no. 7580 , diluted $13 \mu \mathrm{l} / \mathrm{ml}$ of blocking solution/ each for $30 \mathrm{~min}$. The slides were washed in PBS and further treated with biotinylated secondary antibody and $A B C$ reagents as recommended by the manufacturer (Vectastain $A B C$ kit, Elite mouse IgG, PK6102, Vector Laboratories).

\section{Acknowledgments}

We thank Dr. C.C. Hui for advice on bone staining, Drs. C.M. Morshead and D. van der Kooy for advise on BrdU staining, Dr. S.A. Ben-Sasson for advice on TUNEL staining, Drs. M. Rudnicki, J. Squire, and T. Ried for discussions regarding the large myotomal nuclei, Steven Doyle for assistance with electron microscopy, and G. Fidalgo for assistance in preparation of DNA. E. Zacksenhaus was supported in part by an NCI postdoctoral fellowship. This work was supported by the National Cancer Institute of Canada with funds from the Terry Fox Run; the Medical Research Council of Canada; the Canadian Genetic Disease Network; the Retinoblastoma Family Association; and the Royal Arch Masons of Canada.

The publication costs of this article were defrayed in part by payment of page charges. This article must therefore be hereby marked "advertisement" in accordance with 18 USC section 1734 solely to indicate this fact.

\section{References}

Andres, V. and K. Walsh. 1996. Myogenin expression, cell cycle withdrawal and phenotypic differentiation are temporally separable events that precede cell fusion upon myogenesis. $I$. Cell Biol. 132: 657-666.

Bernards, R., G.M. Schackleford, M.R. Gerber, J.M. Horowitz, S.H. Friend, M. Schartl, E. Bogenmann, J.M. Rapaport, T. McGee, T.P. Dryja, and R.A. Weinberg. 1989. Structure and expression of the murine retinoblastoma gene and characterization of its encoded protein. Proc. Natl. Acad. Sci. 86: 6474-6478.

Bignon, Y.J., Y. Chen, C.Y. Chang, D.J. Riley, J.J. Windle, P.L. Mellon, and W.H. Lee. 1993. Expression of a retinoblastoma transgene results in dwarf mice. Genes \& Dev. 7: 1654 1662.

Blau, H.M. 1993. Differentiation requires continuous active control. Annu. Rev. Biochem. 61: 1213-1230.

Bober, E., G.E. Lyons, T. Braun, G. Cossu, M. Buckingham, and H.H. Arnold. 1991. The muscle regulatory gene, Myf-6, has a biphasic pattern of expression during early mouse development. J. Cell. Biol. 113: 1255-1265.

Braun, T. and H.H. Arnold. 1996. myf-5 and myoD genes are activated in distinct mesenchymal stem cells and determine different skeletal muscle cell lineages. EMBO J. 15: 310-318.

Braun, T., G. Buschhausen-Denker, E. Bober, E. Tannich, and H.H. Arnold. 1989. A novel human muscle factor related to but distinct from MyoD1 induces myogenic conversion in 10T1/2 fibroblasts. EMBO I. 8: 701-709.

Braun, T., E. Bober, B. Winter, N. Rosenthal, and H.H. Arnold. 1990. Myf-6, a new member of the human gene family of myogenic determination factors: Evidence for a gene cluster on chromosome 12. EMBO I. 9: 821-831.

Buckingham, M. 1992. Making muscle in mammals. Trends Genet. 8: 144-148.

Clarke, A.R., E.R. Maandag, M. Van Roon, N.M.T. Van der Lugt, M. Van der Valk, M.L. Hooper, A. Berns, and H. Te Riele. 1992. Requirement for a functional Rb-l gene in murine development. Nature 359: 328-330.

Davis, R.L., H. Weintraub, and A.B. Lassar. 1987. Expression of a single transfected cDNA converts fibroblasts to myoblasts. Cell 51: 987-1000.

Defeo-Jones, D., P.S. Huang, R.E. Jones, K.M. Haskell, G.A. Vuocolo, M.G. Hanobik, H.E. Huber, and A. Oliff. 1991. Cloning of cDNAs for cellular proteins that bind to the retinoblastoma gene product. Nature 352: 251-254.

Deng, C., P. Zhang, J.W. Harper, S.J. Elledge, and P. Leder. 1995. Mice lacking p21CIP1/WAF1 undergo normal development, but are defective in G1 checkpoint control. Cell 82: 675684.

Dunaief, J.L., B.E. Strober, S. Guha, P.A. Khavari, K. Ålin, J. Luban, M. Begemann, G.R. Crabtree, and S.P. Goff. 1994. The retinoblastoma protein and BRG1 form a complex and cooperate to induce cell cycle arrest. Cell 79: 119-130.

Edmondson, D.G. and E.N. Olson. 1989. A gene with homology to the myc similarity region of MyoDl is expressed during myogenesis and is sufficient to activate the muscle differentiation program. Genes \& Dev. 3: 628-640.

Ewen, M., Y. Xing, J.B. Lawrence, and D. Livingston. 1991. Molecular cloning, chromosomal mapping, and expression of the cDNA for p107, a retinoblastoma gene product-related protein. Cell 66: 1155-1164.

Fiddler, T.A., L. Smith, S.J. Tapscott, and M.J. Thayer. 1966. Amplification of MDM2 inhibits MyoD-mediated myogenesis. Mol. Cell. Biol. 16: 5048-5057.

Field, S.J., F.Y. Tsai, F. Kuo, A.M. Zubiage, W.G. Kaelin, D.M. Livingston, S.H. Orkin, and M.E. Greenberg. 1996. E2F-1 functions in mice to promote apoptosis and suppress proliferation. Cell 85: 549-561.

Gavrieli, Y., Y. Sherman, and S.A. Ben-Sasson. 1992. Identification of programmed cell death in situ via specific labeling of nuclear DNA fragmentation. $J$. Cell. Biol. 119: 493-501.

Gu, W., J.W. Schneider, G. Condorelli, S. Kaushal, V. Mahdavi, and B. Nadal-Ginard. 1993. Interaction of myogenic factors and the retinoblastoma protein mediates muscle cell commitment and differentiation. Cell 72: 309-324.

Hagemeier, C., A.J. Bannister, A. Cook, and T. Kouzarides. 1993. The activation domain of transcription factor PU.1 binds the retinoblastoma (RB) protein and the transcription factor TFIID in vitro: RB shows sequence similarity to TFIID and TFIIB. Proc. Natl. Acad. Sci. 90: 1580-1584.

Halevy, O., B.G. Novitch, D.B. Spicer, S.X. Skapek, J. Rhee, G.J. Hannon, D. Beach, and A.B. Lassar. 1995. Correlation of terminal cell cycle arrest of skeletal muscle with induction of p21 by MyoD. Science 267: 1018-1021.

Hannon, G.J., D. Demetrick, and D. Beach. 1993. Isolation of the Rb-related p130 through its interaction with CDK2 and cyclins. Genes \& Dev. 7: 2378-2391.

Hasty, P., A. Bradley, J.H. Morris, D.G. Edmondson, J.M. Venuti, E.N. Olson, and W.H. Klein. 1993. Muscle defi- 
ciency and neonatal death in mice with a targeted mutation in the myogenin gene. Nature 364: 501-506.

Hijmans, E.M., P.M. Voorhoeve, R.L. Beijersbergen, L.J. van't Veer, and R. Bernards. 1995. E2F-5, a new E2F family member that interacts with pl30 in vivo. Mol. Cell. Biol. 15: 3082-3089.

Hinterberger, T.J., D.A. Sassoon, S.J. Rhodes, and S.F. Konieczny. 1991. Expression of the muscle regulatory factor MRF4 during somite and skeletal myofiber development. Dev. Biol. 147: 144-156.

Hong, F.D., H.-J.S. Huang, H. To, L.J. Young, A. Oro, R. Bookstein, E.Y. Lee, and W.H. Lee. 1989. Structure of the human retinoblastoma gene. Proc. Natl. Acad. Sci. 86: 5502-5506.

Huang, S., W.-H. Lee, and E.Y.-H.P. Lee. 1991. A cellular protein that competes with SV40 T antigen for binding to the retinoblastoma gene product. Nature 350: 160-162.

Hui, C.C., D. Slusarski, K.A. Platt, R. Holmgren, and A.L. Joyner. 1994. Expression of three mouse homologs of the Drosophila segment polarity gene cubitus interruptus, Gli, Gli-2, and Gli-3, in ectoderm- and mesoderm-derived tissues suggests multiple roles during postimplantation development. Dev. Biol. 162: 402-413.

Jacks, T., A. Fazeli, E.M. Schmitt, R.T. Bronson, M.A. Goodell, and R.A. Weinberg. 1992. Effects of an $R b$ mutation in the mouse. Nature 359: 295-300.

Jegalian, B.G. and E.M. De Robertis. 1992. Homeotic transformations in the mouse induced by overexpression of a human Hox3.3 transgene. Cell 71: 901-910.

Kim, S.J., S. Wagner, F. Liu, M.A. O'Reilly, P.D. Robbins, and M.R. Green. 1992. Retinoblastoma gene product activates expression of the human TGF-beta 2 gene through transcription factor ATF-2. Nature 358: 331-334.

Kuhar, S.G. and J.M. Lehman. 1991. T antigen and p53 in preand post-crisis simian virus 40-transformed human cell lines. Oncogene 6: 1499-1506.

Lakso, M., B. Sauer, B. Mosinger, E.J. Lee, R.W. Manning, S.-H. Yu, K.L. Mulder, and H. Westphal. 1992. Targeted oncogene activation by site-specific recombination in transgenic mice. Proc. Natl. Acad. Sci. 89: 6232-6236.

Lee, E.Y.-H.P., C.Y. Chang, N. Hu, Y.C.J. Wang, C.C. Lai, K. Herrup, W.H. Lee, and A. Bradley. 1992. Mice deficient for $\mathrm{Rb}$ are nonviable and show defects in neurogenesis and haematopoiesis. Nature 359: 288-294.

Lee, E.Y.-H.P., N. Hu, S.-S.F. Yuan, L.A. Cox, A. Bradley, W.-H. Lee, and K. Herrup. 1994. Dual roles of the retinoblastoma protein in cell cycle regulation and neuron differentiation. Genes \& Dev. 8: 2008-2021.

Lee, M.H., B.O. Williams, G. Mulligan, S. Mukai, R.T. Bronson, N. Dyson, E. Harlow, and T. Jacks. 1996. Targeted disruption of $p 107$ : Functional overlap between $p 107$ and $R b$. Genes \& Dev. 10: 1621-1632.

Li, Y., C. Graham, S. Lacy, A.M. Duncan, and P. Whyte. 1993. The adenovirus ElA-associated $130-\mathrm{kD}$ protein is encoded by a member of the retinoblastoma gene family and physically interacts with cyclins A and E. Genes \& Dev. 7: 23662377.

Lufkin, T., M. Mark, C.P. Hart, P. Dolle, M. LeMeur, and P. Chambon. 1992. Homeotic transformation of the occipital bones of the skull by ectopic expression of a homeobox gene. Nature 359: 835-841.

Lyons, G.E., S. Muhlebach, A. Moser, R. Masood, B.M. Paterson, M.E. Buckingham, and J.C. Perriard. 1991. Developmental regulation of creatine kinase gene expression by myogeninenic factors in embryonic mouse and chick skeletal muscle. Development 113: 1017-1029.

Maandag, E.C.R., M. Van der Valk, M. Vlaar, C. Feltkamp, J.
O'Brien, M. Van Roon, N. Van der Lugt, A. Berns, and H. Te Riele. 1994. Developmental rescue of an embryonic-lethal mutation in the retinoblastoma gene in chimeric mice. EMBO I. 13: 4260-4268.

Miner, J.H. and B.J. Wold. 1990. Herculin, a fourth member of $M y o D$ family of myogenic regulatory genes. Proc. Natl. Acad. Sci. 87: 1089-1093.

Molkentin, J.D., B.L. Black, J.F. Martin, and E.N. Olson. 1995. Cooperative activation of muscle gene expression by MEF2 and myogeninenic bHLH proteins. Cell 83: 1125-1136.

Morgenbesser, S.D., B.O. Williams, T. Jacks, and R.A. DePinho. 1994. p53-dependent apoptosis produced by Rb-deficiency in the developing mouse lens. Nature 371: 72-74.

Morshead, C.M., B.A. Reynolds, C.G. Craig, M.W. McBurney, W.A. Staines, D. Morassutti, S. Weiss, and D. van der Kooy. 1994. Neural stem cells in the adult mammalian forebrain: A relatively quiescent subpopulation of subependymal cells. Neuron 13: 1071-1082.

Nabeshima, Y., K. Hanaoka, M. Hayasaka, E. Esumi, S. Li, and I. Nonaka. 1993. Myogenin gene disruption results in perinatal lethality because of severe muscle defect. Nature 364: 532-535.

Nowakowski, R.S., S.B. Lewin, and M.W. Miller. 1989. Bromodeoxyuridine immunohistochemical determination of the lengths of the cell cycle and the DNA-synthetic phase for an anatomically defined population. I. Neurocytol. 18: 311318.

Olson, E.N. and W.H. Klein. 1994. bHLH factors in muscle development: Dead lines and commitments, what to leave in and what to leave out. Genes \& Dev. 8: 1-8.

Olson, E.N., H.H. Arnold, P.W.J. Rigby, and B.J. Wold. 1996. Know your neighbors: Three phenotypes in null mutants of the myogeninenic bHLH gene MRF4. Cell 85: 1-4.

Orban, P.C., D. Chui, and J.D. Marth. 1992. Tissue- and sitespecific DNA recombination in transgenic mice. Proc. Natl. Acad. Sci. 89: 6861-6865.

Ornitz, D.M., R.E. Hammer, A. Messing, R.D. Palmiter, and R.L. Brinster. 1987. Pancreatic neoplasia induced by SV40 $\mathrm{T}$-antigen expression in acinar cells of transgenic mice. Science 238: 188-193.

Palmiter, R.D., E.P. Sandgren, M.R. Avarbock, D.D. Allen, and R.L. Brinster. 1991. Heterologous introns can enhance expression of transgenes in mice. Proc. Natl. Acad. Sci. 88: 478-482.

Parker, S.B., G. Eichele, P. Zhang, A. Rawls, A.T. Sands, A. Bradley, E.N. Olson, J.W. Harper, and S.J. Elledge. 1995. p53 independent expression of p21Cip1 in muscle and other terminally differentiating cells. Science 267: 1024-1027.

Pin, C.L. and P.A. Merrifield. 1993. Embryonic and fetal rat myoblasts express different phenotypes following differentiation in vitro. Dev. Genet. 14: 356-368.

Rhodes, S.J. and S.F. Konieczny. 1989. Identification of MRF4: A new member of the muscle regulatory factor gene family. Genes \& Dev. 3: 2050-2061.

Rinehart, C.A., J.P. Mayben, T.D. Butler, J.S. Haskill, and D.G. Kaufman. 1992. Alterations of DNA content in human endometrial stromal cells transfected with a temperature-sensitive SV40: Tetraploidization and physiological consequences. Carcinogen 13: 63-68.

Rinehart, C.A., C.H. Laundon, J.P. Mayben, B.D. Lyn-Cook, and D.G. Kaufman. 1993. Conditional immortalization of human endometrial stromal cells with a temperature-sensitive simian virus 40. Carcinogen 14: 993-999.

Rudnicki, M.A., P.N. Schnegelsberg, R.H. Stead, T. Braun, H.H. Arnold, and R. Jaenisch. 1993. MyoD or Myf-5 is required for the formation of skeletal muscle. Cell 75: 1351-1359. 
Sardet, C., M. Vidal, D. Cobrinik, Y. Geng, C. Onufryk, A. Chen, and R.A. Weinberg. 1995. E2F-4 and E2F-5, two members of the E2F family, are expressed in the early phases of the cell cycle. Proc. Natl. Acad. Sci. 92: 2403-2407.

Sassoon, D.A., I. Garner, and M. Buckingham. 1988. Transcripts of alpha-cardiac and alpha-skeletal actins are early markers for myogenesis in the mouse embryo. Development 104: 155-164.

Sassoon, D.A., G. Lyons, W.E. Wright, V. Lin, A. Lassar, H. Weintraub, and M. Buckingham. 1989. Expression of two myogenic regulatory factors myogenin and MyoDl during mouse embryogenesis. Nature 341: 303-307

Schneider, J.W., W. Gu, L. Zhu, V. Mahdavi, and B. Nadal-Ginard. 1994. Reversal of terminal differentiation mediated by pl07 in $\mathrm{RB}^{-1-}$ muscle cells. Science 264: 1467-1471.

Seigel, G.M. and M.F. Notter. 1993. Differentiation of Y79 retinoblastoma cells induced by succinylated concanavalin A. Cell Growth Diff. 4: 1-7.

Seigel, G.M., J. Tombran-Tink, S.P. Becerra, G.J. Chader, D.A. Diloreto, Jr., C. Del Cerro, E.S. Lazar, and M. Del Cerro. 1994. Differentiation of Y79 retinoblastoma cells with pigment epithelial-derived factor and interphotoreceptor matrix wash: Effects on tumorigenicity. Growth Factors 10: 289-297.

Sherr, C.J. and J.M. Roberts. 1995. Inhibitors of mammalian $G_{1}$ cyclin-dependent kinases. Genes \& Dev. 9: 1149-1163.

Singh, P., J. Coe, and W. Hong. 1995. A role for retinoblastoma protein in potentiating transcriptional activation by the glucocorticoid receptor. Nature 374: 562-565.

Skapek, S.X., J. Rhee, D.B. Spicer, and A.B. Lassar. 1995. Inhibition of myogenic differentiation in proliferating myoblasts by cyclin D1-dependent kinase. Science 267: 1022-1024.

Vairo, G., D.M. Livingston, and D. Ginsberg. 1995. Functional interaction between E2F-4 and p130: Evidence for distinct mechanisms underlying growth suppression by different retinoblastoma protein family members. Genes \& Dev. 9: 869881.

Wang, C.Y., B. Petryniak, C.B. Thompson, W.G. Kaelin, and J.M. Leiden. 1993. Regulation of the Ets-related transcription factor Elf- 1 by binding to the retinoblastoma protein. Science 260: 1330-1335.

Wang, J. and K. Walsh. 1996. Resistance to apoptosis conferred by cdk inhibitors during myocyte differentiation. Science 273: 359-361.

Weinberg, R.A. 1995. The retinoblastoma protein and cell cycle control. Cell 81: 323-330.

Weintraub, H. 1993. The MyoD family and myogenesis: Redundancy, networks, and thresholds. Cell 75: 1241-1244.

Weintraub, S.J., C.A. Prater, and D.C. Dean. 1992. Retinoblastoma protein switches the E2F site from positive to negative element. Nature 358: 259-261.

Weintraub, S.J., K.N.B. Chow, R.X. Luo, S.H. Zhang, S. He, and D.C. Dean. 1995. Mechanism of active transcriptional repression by the retinoblastoma protein. Nature 375: 812815.

Welch, P.J. and J.Y. Wang. 1993. A C-terminal protein-binding domain in the retinoblastoma protein regulates nuclear c-Abl tyrosine kinase in the cell cycle. Cell 75: 779-790.

Williams, B.O., E.M. Schmitt, L. Remington, R.T. Bronson, D.M. Albert, R.A. Weinberg, and T. Jacks. 1994. Extensive contribution of $\mathrm{Rb}$-deficient cells to adult chimeric mice with limited histopathological consequences. EMBO $/$. 13: 4251-4259.

Wright, W.E., D.A. Sassoon, and V.K. Lin. 1989. Myogenin, a factor regulating myogenesis, has a domain homologous to MyoD. Cell 56: 607-617.
Xiao, Z.-X., J. Chen, A.J. Levine, N. Modjtahedi, J. Xing, W.R Sellers, and D.M. Livingston. 1995. Interaction between the retinoblastoma protein and the oncoprotein MDM2. Nature 375: 694-698.

Yamasaki, L., T. Jacks, R. Bronson, E. Goillot, E. Harlow, and N.J. Dyson. 1996. Tumor induction and tissue atrophy in mice lacking E2F-1. Cell 85: 537-548.

Zacksenhaus, E., R. Bremner, Z. Jiang, R.M. Gill, M. Muncaster, M. Sopta, R.A. Phillips, and B.L. Gallie. 1993a. Unraveling the function of the retinoblastoma gene. Adv. Cancer Res. 61: 115-141.

Zacksenhaus, E., R. Bremner, R.A. Phillips, and B.L. Gallie. 1993b. A bipartite nuclear localization signal in the retinoblastoma gene product and its importance for biological activity. Mol. Cell. Biol. 13: 4588-4599.

Zacksenhaus, E., R.M. Gill, R.A. Phillips, and B.L. Gallie. 1993c. Molecular cloning and characterization of the mouse RBl promoter. Oncogene 8: 2343-2351.

Zacksenhaus, E., Z. Jiang, R.A. Phillips, and B.L. Gallie. 1996. Dual mechanisms of repression of E2Fl activity by the retinoblastoma gene product. $E M B O J$. (in press).

Zhang, W., R.R. Behringer, and E.N. Olson. 1995. Inactivation of the myogenic bHLH gene MRF4 results in up-regulation of myogenin and rib anomalies. Genes \& Dev. 9: 1388-1399. 


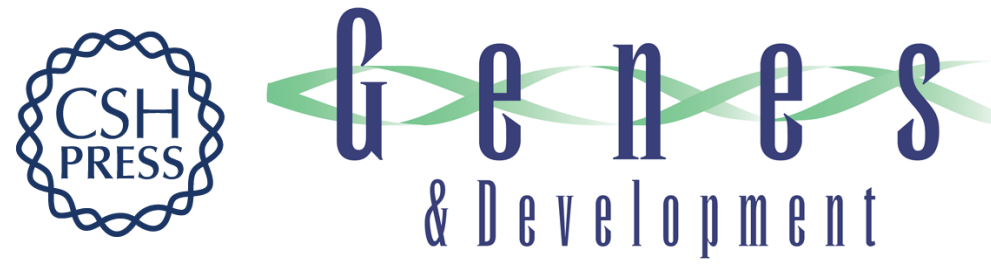

\section{pRb controls proliferation, differentiation, and death of skeletal muscle cells and other lineages during embryogenesis.}

E Zacksenhaus, Z Jiang, D Chung, et al.

Genes Dev. 1996, 10:

Access the most recent version at doi:10.1101/gad.10.23.3051

References This article cites 83 articles, 32 of which can be accessed free at:

http://genesdev.cshlp.org/content/10/23/3051.full.html\#ref-list-1

License

Email Alerting

Service

Receive free email alerts when new articles cite this article - sign up in the box at the top right corner of the article or click here.

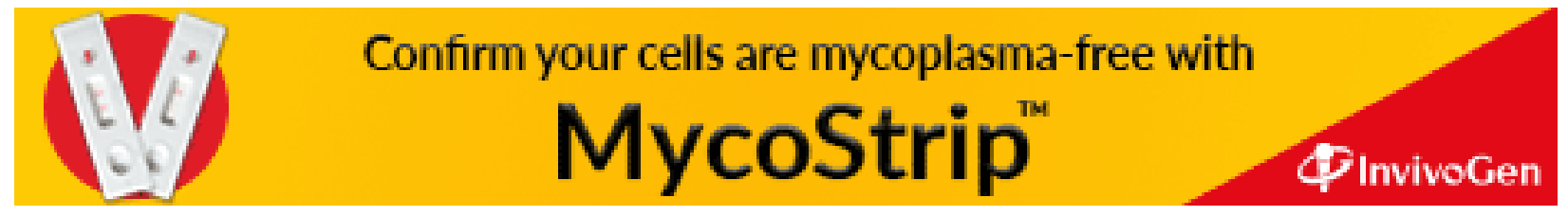

